\title{
Warwick Edwards
}

\section{Agricola's Songs Without Words The Sources and the Performing Traditions}

In 1538 the Nuremberg printer Hieronymus Formschneider issued a set of part-books entitled Trium vocum carmina ${ }^{1}$ and containing a retrospective collection of one hundred untexted and unattributed three-voice compositions, six of which can be assigned to Agricola. Whoever selected them and commissioned the publication added a preface (transcribed, with English translation in Appendix pp. 118-9) that offers - most unusually for the time - a specific explanation for leaving out all the words. This turns out to have nothing to do with performance, let alone the possible use of instruments, which are neither ruled in nor ruled out. Nor does it express any worries about readers' appetites for texts in foreign languages, or mention that some texts probably never existed in the first place. Instead, the author pleads, rather surprisingly, that the appearance of the books would have been spoilt had words variously in German, French, Italian and Latin been mixed in together. Moreover, the preface continues, the composers of the songs had regard for erudite sonorities rather than words. The learned musician, then, will enjoy the contents all the more for such sounds not being subject to the words. To this end the author even justifies leaving all the songs without attributions on the grounds that learned readers will be able to identify the composers readily from the individual stamp each gives to his music. ${ }^{2}$

1 Trivm vocvm carmina a diversis musicis composita (Nuremberg: Hieronymus Formschneider, 1538), RISM $1538^{9}$.

2 Regarding the last point we may note that both surviving copies (at D-Bhm and D-Ju) contain sporadic handwritten annotations with text incipits and names of composers. The latter are not always credible: Agricola's »Si dedero«, for example, is attributed to Jacob Obrecht in the Berlin copy. See further Klaus Holzmann, Hieronymus Formschneyders Sammeldruck Trium Vocum Carmina. Nürnberg 1538, diss. Albert-Ludwigs-Universität Freiburg i. Br., 1956); Howard Mayer Brown, Instrumental Music Printed Before 1600: A Bibliography (rev. reprint, Cambridge, Mass., 1967), pp. 59-62; thematic inventory in Norbert Böker-Heil, Harald Heckmann, and Ilse Kindermann, Das Tenorlied. Mehrstimmige Lieder in deutschen Quellen 1450-1580, vol. 1 (Kassel, 1979), pp. 83-91; another list of contents and concordances, with brief discussion, in Armin Brinzing, Studien zur instrumentalen Ensemblemusik im deutschsprachigen Raum des 16. Jabrbunderts. Abhandlungen zur Musikgeschichte 4 (Göttingen, 1998), vol. 1, pp. 47-60; ed. Helmut Mönkemeyer, 2 vols. (Celle, 1985); facs. edn. (Cologne, 1995). 
The emphasis here on the visual representation of music, the view that composers from Ockeghem's time to the present ${ }^{3}$ think in terms of music's intrinsic sounds to the extent that when such sounds can be described in terms of »a well-trained mingling « (»sonorum eruditam mixturam«) they enjoy an elevated status which might be compromised by the distracting presence of mere words, the assumption that readers are well appraised of what distinguishes the music of one composer from another, and above all the tacit indifference to the medium of performance - all represent lines of thought of potentially crucial relevance to Agricola and the idea of $\gg$ Musik zwischen Vokalität und Instrumentalismus«. And they are all the more remarkable for being expressed well after the composer's death, just at the time when other publishers were beginning to claim the contents of their collections as suitable for instrumental ensemble as well as voices, and when composers were increasingly producing works with melodies deliberately and consistently shaped according to the precise prosody of the words they bore, a notational style characterized by renewed clarity of syllable-note alignment, and finally a body of theory to reflect this.

It seems worthwhile, then, to ask what such an apparently old-fashioned approach to presentation might have in common with that assumed by Agricola himself, and by the individuals who transmitted and performed his music across Europe during his lifetime. In what follows I shall attempt a fresh look at the phenomenon of wordless transmission and what it signifies in Agricola sources generally. I shall then turn to Agricola himself, reviewing the extent to which his compositions can be usefully characterized as ssongs with or without words $<$, while at the same time considering their respective performing traditions.

\section{The sources}

\section{French}

It makes sense to begin discussion of transmission with French sources. With their apparent close ties to the French royal court, the earlier chansonniers that contain Agricola's work seem not so distant from him, either in presentation or in terms of their relationships to the circles in which we may

3 One assumes compilation more-or-less contemporaneous with publication, though since the youngest composer identifiable - Arnold von Bruck - may have been born around 1500 the possibility that the collection might have been compiled up to, say, ten years earlier cannot be ruled out entirely. 
surmise he moved. ${ }^{4}$ Admittedly uncertainties surround both: there are no known autographs, and we lack documentation for his whereabouts for fifteen years following his departure as a young man from Cambrai in 1476. Still, we at least know that he had been employed in Charles VIII's chapelle immediately before and after his first documented sojourn in Italy in 1491-2. ${ }^{5}$

At first sight the issue of wordless presentation scarcely seems to arise in these sources. They almost invariably include words underlaid to at least the top voice. There is, however, the matter of partial texting. The chansonniers into which his songs were copied in the 1480s present them, like those of other composers, with lower voices untexted (save, in some instances, for incipits). The practice of setting out all voices with full text, while not new, begins to be the norm only from the 1490 s onwards. ${ }^{6}$ Partial texting seems to go back to virtually the beginnings of polyphony. Were the presence of individual voices without words applicable to just vernacular song it might be conjectured that they signify the participation of instrumentalists in performance. But since they are characteristic of Latin devotional music too (see, for example, the Cambrai Cathedral choirbooks, F-CA, 6 and 11, copied in the 1430s and 1440s, respectively, the latter by Simon Mellet) ${ }^{7}$ in the performance of which instrumental participation was plainly exceptional before Agricola's time, this inference will not do. Rather it would seem that

4 The sources from the 1480s are the later layers of F-Pn, Rés. Vmc.57 (Nivelle chansonnier), F-Dm, 517 (Dijon chansonnier), US-Wc, M2.1 L25 Case (Laborde chansonnier), I-Fr, 2794, GB-Lbl, Royal 20.A.xvi (earlier layer). The last mentioned comprises what looks like an uninterrupted sequence of eleven (twelve?) chansons by Agricola followed by five (four?) by Hayne van Ghizeghem (attributions are lacking, but can be supplied from other sources in all save two cases in the Agricola section and one in the Hayne; the pivotal twelfth song has conflicting ascriptions in other sources to both composers).

5 At the time of writing Rob C. Wegman's excellent portrayal of Agricola's life in his article "Agricola, Alexander, « The New Grove Dictionary of Music and Musicians, second edn. (London, 2001), vol. 1, p. 225-229, has yet to be updated to take account of Joshua Rifkin's »Alexander Agricola and Cambrai. A Postscript, Tijdschrift van de Koninklijke Vereniging voor Nederlandse Muziekgeschiedenis 44 (2004), pp. 23-30. In the latter newly published documentation on Agricola's brief employment at Cambrai both forces a revision to the received date for his birth from ? $1445 / 6$ to c. 1455 and confirms that Wegman was right to question his former identification with Alessandro de Alemania (and with it the supposition that he travelled to Italy before 1491).

6 GB-Lbl, Royal 20.A.xvi (later layer), but with only two Agricola songs.

7 Cambrai Cathedral Choirbook: Cambrai Bibliothèque municipale MS 11, facs. edn., introd. Liane Curtis (Peer, 1992). See also Liane Curtis, »The Origins of Cambrai, Bibliothèque municipale manuscript 6 and its Relationship to Cambrai 11, «Tijdschrift van de Vereniging voor Nederlandse Muziekgeschiedenis 44 (1994), pp. 6-35. Sadly no such French collections of sacred music survive from Agricola's time. 
partial texting is symptomatic of a process transcending genre and language whereby scribes (and by implication composers) conceive some voices in terms of the words they are to bear, and others without deliberate reference to them at all. Textlessness in itself, then, tells us nothing about performance practice. We need to look to other kinds of evidence to try to determine the circumstances in which such voices might be played on instruments, adapted to bear words, or simply vocalized. While such evidence is far from conclusive, the weight of what we have from contemporary documents points to $a$ cappella performance as the norm in fourteenth- and fifteenth-century vernacular polyphonic song as in Latin devotional music - and right across Europe. ${ }^{8}$

Consideration of the implications of partial texting is a pre-requisite for coming to terms with the few instances of songs copied into French sources with virtually no words at all. Cases in point by Agricola include his Oblier veult douleur et tristesse (in F-Pn, fr. 1596, compiled c. 1500), In mijnen sin (in F-Pn, fr. 2245, dated 1496-8), Comme femme desconfortée a 3 (in F-Pn, fr. 1597, perhaps c. 1500 or a little later), and Revenez tous, regretz / Quis det ut veniat (upper three voices untexted in the Savoyard B-Br, 11239, c. 1500 or a little later, the first chanson album of Marguerite of Austria), ${ }^{9}$ as well as half the twelve songs and motets by him in the posthumous DK-Kk, 1848 (Lyon, c. 1525). Later we shall examine the extent to which some of these compositions may have been associated from the start with instrumental performing traditions. For the present it is sufficient to note that the sources

8 See further Christopher Page, »Machaut's >pupil Deschamps on the Performance of Music: Voices or Instruments in the $14^{\text {th }}$-Century Chanson?, « Early Music 5 (1977), pp. 484-91, reprinted in Page, Music and Instruments of the Middle Ages: Studies on Texts and Performance (Aldershot, 1997); Craig Wright, »Voices and Instruments in the Art Music of Northern France during the $15^{\text {th }}$ Century: A Conspectus, «International Musicological Society. Report of the Twelfth Congress Berkeley 1977, ed. Daniel Heartz and Bonnie Wade (Kassel, 1981), pp. 643-9; David Fallows, "Specific Information on the Ensembles for Composed Polyphony, 1400-1474, «Studies in the Performance of Late Medieval Music, ed. Stanley Boorman (Cambridge, 1983), pp. 109-44, esp. on pp. 126-44, reprinted in Fallows, Songs and Musicians in the Fifteenth Century (Aldershot, 1996). For an evaluation of the 1980s debate about the vocal or instrumental performance of the lower voices of chansons see Daniel Leech-Wilkinson, The Modern Invention of Medieval Music: Scholarship, Ideology, Performance (Cambridge, 2002), especially the first two chapters.

9 Honey Meconi questions the Savoy assumption (»Pierre de la Rue and Secular Music at the Court of Marguerite of Austria, «Muziek aan het Hof van Margaretha van Oostenrijk. Jaarboek van het Vlaamse Centrum voor Oude Muziek 3, Peer, 1987, p. 50), subsequently maintaining, in spite of Joshua Rifkin's scepticism (»Busnoys and Italy: The Evidence of Two Songs, "Antoine Busnoys: Method, Meaning, and Context in Late Medieval Music, ed. Paula Higgins, Oxford, 1999, p. 525), that northern French origin is also possible (Pierre de la Rue and Musical Life at the Habsburg-Burgundian Court, Oxford, 2003, pp. 135-6). 
that present them yield no more evidence of realisation by instruments than they do in the case of partially texted compositions.

\section{Flemish}

The same is arguable for most if not all extant Agricola sources from beyond France. Certain manuscripts compiled by Dutch-speaking scribes are rich in his compositions, as one might expect given his Ghent upbringing and latterly his employment with Philip the Fair. Those devoted to sacred music all belong to the so-called Burgundian-Habsburg complex, copied from around 1500 in Brussels and Mechelen for a variety of clients at home and abroad. ${ }^{10}$ In such collections words again accompany the top voices and are usually implied, if not explicit, in all the lower ones. This applies also to some of the few surviving sources from the region with his French (and occasionally Flemish) songs. ${ }^{11}$ Two books, however, have conspicuous quantities of untexted items, and it is surely no accident that both were evidently compiled for consumption in lands to which foreign vernaculars would not travel so easily.

As it happens, the earlier book, known as the Segovia Manuscript (E-SE, s.s.), was compiled in Spain, but for the greater part by a scribe whose contacts with Flanders (Bruges in particular) are so close, and whose Flemish orthography is so good, that, as Joshua Rifkin observed, it is surely the product of an émigré Netherlander, or perhaps »the Castilian-born child of a Flemish parent $\ll .{ }^{12}$ Copying around 1500 (exactly when and where is hard to determine), this scribe provided texts for most, but by no means all of the Latin items, but withheld them from virtually everything with Flemish or

10 See The Treasury of Petrus Alamire: Music and Art in Flemish Court Manuscripts 1500-1535, ed. Herbert Kellman (Ghent, 1999).

11 The fragment GB-Ob, Ashmolean 831 (with two Agricola chansons, though one is ascribed elsewhere to Hayne), B-Br, 228 (the second chanson album of Marguerite of Austria, five chansons, texted in all voices), and B-Br, II/270 (»In mijnen sin«, in version with Flemish sacred parody text), GB-Lbl, Add. 35087 (one Agricola song and one motet, both texted in all three voices).

12 On the manuscript as a whole see Norma Klein Baker, An Unnumbered Manuscript of Polyphony in the Archives of the Cathedral of Segovia: Its Provenance and History (Ph.D. diss., University of Maryland, 1978), especially the section regarding palaeography and the principal scribe's characteristic Castilian script on pp. 92-108. On the Bruges links see Reinhard Strohm, Music in Late Medieval Bruges (Oxford, 1985), pp. 142-4. On the orthography see Rob C. Wegman, Born for the Muses: The Life and Masses of Jacob Obrecht (Oxford, 1994), p. 22. On the likelihood that the principal scribe was of Flemish origin, and for a speculative identification, see Rifkin, Busnoys and Italy (cf. fn. 9), p. 528. 
French titles. Among the repertory copied are nineteen textless pieces attributable to Agricola. Many commentators assume such copies to be »instrumental in function, ${ }^{13}$ but while several pieces may well have originated that way, and in one instance - Roelkin's two-voice De tous biens plaine - that is to all intents and purposes the only kind of performance possible on account of range (the upper voice spans an interval of a nineteenth),${ }^{14}$ it has to be said that there is no direct evidence to support this generalization. The scribe's aim was above all the provision of a wide span of notated Franco-Flemish music. Latin texts could be supplied if to hand, but, like the vernaculars, were dispensable. The different scribes who concluded the collection with some forty Spanish works had a quite different purpose: all but one of these items are fully texted.

The other source with many textless items is I-Fc, Basevi 2439, copied at Mechelen around 1505-8, probably just after Agricola's death, for a Florentine recipient. ${ }^{15}$ Here vernacular text is withheld less consistently than had been the case in the Segovia Manuscript. Even so, there is no guarantee that such words as the scribe chose to copy (perhaps according to ready accessibility of exemplars) were voiced or readily understood abroad. Nor is there specific evidence for or against the supposition that the textless compositions, when received in Florence, were necessarily performed there by instrumentalists, even those items that seem to have been wordless, and probably instrumental, by origin. Again, it was the supply of music that was of the essence.

Italian

If Franco-Flemish sources represent Agricola as >locak composer, those from Italy, Germany, and (in a single instance) England, testify to his reputation

13 See, for example Strohm, Music, ibid., p. 144.

14 It is also in PL-Wu, 5892, and I-PEc, 1013. On potential traps associated with judging instrumentality on range alone see David Fallows, »The >Only< Firmly Instrumental Piece: A Commentary on Benvenuto Dissertori, «I codici musicali Trentini: Nuovi scoperte e nuovi orientamenti della ricerca. Atti del convegno internazionale »The Trent Codices: New Findings and New Directions«, Trento ... 1994, ed. Peter Wright (Trento, 1996), pp. 81-92.

15 Basevi Codex. Florence, Biblioteca del Conservatorio, MS 2439, facs. edn., introd. Honey Meconi (Peer, 1990). See also her »The manuscript Basevi 2439 and chanson transmission in Italy, "Trasmissione e recenzione delle forme di cultura musicale. Atti del XIV congresso della società internazionale di musicologia, Bologna, Ferrara, Parma ... 1987, ed. Angelo Pompilio, Donatella Restani, Lorenzo Bianconi and F. Alberto Gallo (Turin, 1990), vol. 3, pp. 163-74; and her »Sacred Tricinia and Basevi 2439, «I Tatti Studies: Essays in the Renaissance 4 (1991), pp. 151-99. 
internationally. Until recently the relatively high number of Agricola sources compiled in Italy was thought to reflect - at least in part - his supposed long residence there, especially in Florence. However, with revisions to Agricola biography ${ }^{16}$ this explanation is no longer valid. It is in any case plain that, for whatever reason, the survival rate for music books at this time is higher in Italy than elsewhere in Europe, and that the evident Italian predilection for imported Franco-Flemish repertories over native ones was without regard to the physical presence of their composers in the peninsular. ${ }^{17}$

Louise Litterick, in an influential article on the transmission of FrancoFlemish secular music in France and Italy during the last quarter of the fifteenth century, noted a $»$ gradual dwindling of text « over the period in Italian manuscripts, with their mainly imported repertories, in striking contrast with the stable texting exhibited in contemporaneous French sources. It led her to the somewhat hasty conclusion that »The absence of texts in Italian sources is surely an indication of instrumental performance «, and that because foreign texts when present tend to be garbled »it seems hardly possible that anyone could have sung from these manuscripts $\ll{ }^{18}$ This is problematic. To begin with, the article appeared too soon to take full account of the debate, alluded to above, as to what textless parts signify generally in terms of performance. Even so, it is far from self-evident why notational change that is evolutionary in nature should reflect a phenomenon so sharply defined as a switch from voice to instrument in performance.

In any event, a year later Litterick pressed her view with a more emphatic and far-reaching assertion:

Briefly, it has become clear that virtually all Italian sources containing chansons and related genres - a sizeable body of manuscripts originating in Florence, Naples, and various north Italian centres, as well as Petrucci's first prints - were intended for use by instrumentalists and that virtually all of the music in them written by composers active in Italy was destined from the start for instrumental performance. Indeed, this large group of ensemble pieces, which drew on the talents of figures as significant as Martini, Josquin, Isaac, and others, represents the chief focus of secular composition by Franco-Netherlanders in Italy. ${ }^{19}$

16 See fn. 5.

17 See esp. Reinhard Strohm, »Instrumentale Ensemblemusik vor 1500: das Zeugnis der mitteleuropäischen Quellen, « Musik und Tanz zur Zeit Kaiser Maximilian I. Bericht über die ... 1989 in Innsbruck abgehaltene Fachtagung. Innsbrucker Beiträge zur Musikwissenschaft 15, ed. Walter Salmen (Innsbruck, 1992), p. 89.

18 Louise Litterick, »Performing Franco-Netherlandish Secular Music of the Late 15th Century: Texted and Untexted Parts, Early Music 8 (1980), pp. 478-80.

19 Louise Litterick, »On Italian Instrumental Ensemble Music in the Late Fifteenth Century, « 
I will return at the end of the essay to the assumption, already touched on, that links putative instrumental repertory in the sources with composers ractive in Italy<. For the present my concern is that such a sweeping view of Italian secular sources raises important questions about the purposes and functions of notated music when collected together and presented in book form, and about the transmission of vernaculars from one language-speaking area to another.

In this connection it is apposite to ponder the quantity of music that must have been sent or carried from these northern language areas to Italy and elsewhere in the form of bifolia or small fascicles, and used there as exemplars for the compilation of more formal musical collections. Some such fascicles, one assumes, included full texts (reflecting normal practice in manuscripts compiled in the north for home consumption). The Florentine copyist of F-Pn, fr. 15123 (Pixérécourt chansonnier) presumably worked almost entirely from texted models (he consistently transmits excellent readings of the music but garbled ones of the words). The sporadic and often utterly unusable French texts that appear in several other Italian Agricola sources must similarly derive ultimately from materials prepared and texted by Franco-Flemish scribes. ${ }^{20}$ The untexted items in these books may sometimes reflect the state of what was being copied. However, in other instances they must have resulted from the dropping of text present in the exemplar but now considered redundant. Blake Wilson recently warned against jumping to conclusions regarding what this might imply:

The assumption that the textless transmission of vocal works indicates instrumental performance needs to be tempered by consideration of the immediate context of the source in question. Panciatichi 27 [for example] was probably intended for use in a clerical environment where the interest was in collecting all kinds of music and outfitting it with sacred texts (both Latin and Italian). ... The Florentine cantasi come practice is directly related to the city's chansonniers, and this context suggests that one of the intentions of the compilers of these anthologies was the retrofitting of untexted chansons with Italian lauda texts. ${ }^{21}$

Music in Medieval and Early Modern Europe: Patronage, Sources and Texts, ed. Iain Fenlon (Cambridge, 1981), p. 117.

20 For example, the portions of the originally Neapolitan Colombina chansonnier (E-Sc, 5-1-43, together with F-Pn, n.a.fr. 4379, fols. 1-42) in an Italian hand, I-Fr, 2356, and I-Fn, B.R. 229 from Florence, I-Fr, Panc. 27 (of uncertain origin), and F-Pn, Rés. Vm ${ }^{7}$ 676 (Mantua, 1502).

21 Blake Wilson, »Heinrich Isaac among the Florentines, « Journal of Musicology 23 (2006), p. 145 . 
Admittedly, some scribes seem to have dropped texts more or less systematically, regardless of the state of their exemplars, ${ }^{22}$ or adopted a systematic distinction between texted and untexted items. ${ }^{23}$ Here we may wonder whether instrumental performance is not more compellingly implied. Indeed, as Litterick notes:

This is explicitly documented in the case of Rome 2856, the earliest manuscript lacking any text other than incipits. A record of payment to its copyist describes the book as being written >a la pifaresca<, which clearly points to use by wind players. ${ }^{24}$

This conclusion too is unsafe, however, because although the manuscript in question (I-Rc, 2856) bears the joint arms of the Este and Gonzaga families, and hence is associated with Ferrara where the payment was recorded, apparently between 1479 and 1481, to the ducal singer Alessandro Signorello, evidence linking it with the transaction is shaky: the manuscript lacks the ducal arms referred to in the payment document and any corroborative indication of its scribe's identity. Moreover, with only its seventh piece ascribed to Antoine Brumel (born 1460), to say nothing of the several pieces ascribed to Agricola, Obrecht and Josquin, with their dates of birth now revised to the mid-1450s, José María Llorens's original estimated compilation date c. 1490 continues to look more credible than anything significantly earlier, a point recently underlined by Rifkin. ${ }^{25}$ The link cannot be ruled out, but neither can it be ruled in.

Still, the Ferrarese payment record at least provides evidence for the production there of music books specifically designed for wind players. And it is tempting to surmise that, even if the book Signorello copied was not Rome 2856, it nevertheless contained a similar textless repertory. After all, being compiled locally, both books might have drawn on common exemplars, an attractive possibility given that a few pieces in the manuscript we do have show signs of adaptation apparently to fit the ranges of wind instru-

22 Those with Agricola compositions being I-Bc, Q 16 (Naples; just two texted items); I-Rvat, C.G. 27, I-Fn, Magl. XIX. 178, and I-Fn, Magl. XIX. 107b (Florence); I-Rc, 2856 (Ferrara), I-VEcap, 757 (Verona?).

23 I-Bc, Q 18 (Bologna).

24 Litterick, Performing (cf. fn. 17), p. 480.

25 Joshua Rifkin, »Munich, Milan, and a Marian Motet: Dating Josquin’s >Ave Maria ... virgo serena<, Journal of the American Musicological Society 56 (2003), on pp. 313-26. Rifkin summarizes the considerable literature on this manuscript over recent years. For a necessarily brief pre-publication response by Lewis Lockwood see the »Addendum« to his introduction to the facs. edn. A Ferrarese Chansonnier: Roma, Biblioteca Casanatense 2856. »Canzoniere di Isabella d'Este«, ed. Lewis Lockwood (Lucca, 2002), pp. xxxi-xxxii. 
ments. ${ }^{26}$ However, the fact remains that we do not have firm evidence for Rome 2856's putative instrumental function, or indeed for exactly how the contents of the »cantiones a la pifaresca « recorded in the ducal library might have differed from those of the »cantiones francese « (applicable to most of Rome 2856) or »cantiones taliane « in the same collection. It might have been, for example, a collection of ballo melodies such as those in the manuscripts containing Guglielmo Ebreo of Pesaro's earlier treatise on the practice or art of dancing, complementing the »Tenori todeschi in canto« (German tenors for instrumental improvisation) that also graced the library. ${ }^{27}$

The uncertainty that continues to surround Rome 2856's precise function also characterizes other Agricola sources demonstrably compiled in close geographical proximity to the operational spheres of particular instrumentalists. Susan Weiss, for example, showed I-Bc, Q 18 to have been compiled in Bologna between 1502 and 1505 when Bernardino Piffaro (»a literate performer of polyphony«) and other wind players were also present. ${ }^{28}$ However, Weiss did not claim to have demonstrated a tangible link between the manuscript and the musicians, or to have discovered any evidence to support the idea that its copyist thought to categorise the mainly texted first section as vocal and the entirely untexted latter part as instrumental. Similarly William Prizer, having established a Mantua location for a partially texted music book compiled in October 1502 by Ludovico Milliare (F-Pn, $\mathrm{Vm}^{7}$ 676), properly called attention to the presence of instrumentalists there and to the inclusion in the volume of at least some items surely designed to be played rather than sung (though he improperly adduced what he took to be the assured instrumental status of Rome 2856 and Bologna Q 18 in support of his argument for the manuscript's instrumental function).$^{29}$ It might indeed be the case that instrumentalists with musicreading abilities were present at virtually all Italian locations where books of

26 Lewis Lockwood, Music in Renaissance Ferrara 1400-1505: the Creation of a Musical Center in the Fifteenth Century (Cambridge, Mass., 1984), pp. 270-1.

27 For citations of these music books in an undated list and in a subsequent inventory of the ducal library of 1495, see Lockwood, Music, ibid., p. 218. On Ebreo's treatise De pratica sen arte tripudii and its dance melodies see the edn. and transl. by Barbara Sparti (Oxford, 1993).

28 Susan Forscher Weiss, »Bologna Q 18: Some Reflections on Content and Context, « Journal of the American Musicological Society 41 (1988), pp. 63-101.

29 William F. Prizer, »Paris, Biblothèque Nationale, Rés. Vm. ${ }^{7} 676$ and Music at Mantua, « Trasmissione e recenzione (cf. fn. 15), vol. 2, pp. 235-9; ibid., »Instrumental Music / Instrumentally Performed Music ca. 1500: The Genres of Paris, Bibliothèque nationale, Ms. Rés. Vm. ${ }^{7} 676$, «e concert des voix et des instruments à la Renaissance. Actes du XXXIV Colloque International d'Études Humanistes, Tours ... 1991, ed. Jean-Michel Vaccaro (Paris, 1995), pp. 179-98. 
foreign songs were copied either without words or in such a way as make it seem unlikely that words were articulated in performance. Nevertheless, the evidence required to demonstrate a reliable link between textlessness and instrumental performance remains to be established.

It is in the context of these manuscript collections that Ottaviano Petrucci's epoch-making Harmonice musices Odhecaton A (Venice, 1501, RISM 1501) and its successors, Canti B (Venice, 1502, RISM 1502 ${ }^{2}$ ) and Canti $C$ (Venice, 1504, RISM 1504 ${ }^{3}$ ), must be understood. Between them they include eighteen of Agricola's compositions. Petrucci heads his flagship publication with letters from himself and one Bartolomeo Budrio addressed to the Venetian patrician Girolamo Donato. ${ }^{30}$ They serve not so much as a dedication for a single volume as a manifesto for all of his imminently planned issues of songs, motets and masses. In so doing they lend support to Stanley Boorman's view of the publications as »manifestations of Petrucci's concern for the beauty of the finished product - the book, not the performance $\ll .{ }^{31}$ Or, as James Haar recently put it, they are »only marginally concerned with the specific contents of the Odhecaton. Instead, a humanist tone, exalting the whole enterprise of music printing, would seem to be what Petrucci and Bartolomeo were aiming at. $\ll^{32}$

Still, in the course of criticizing previous printers for neglecting measured music or polyphony Petrucci at least itemizes what he sees as its chief applications, and hence why its printed dissemination is desirable and beneficial. Without such music, he writes, »we neither pray to Almighty God« (»non deum optimum maximum propiciamus «), »nor celebrate wedding rites (»non nuptiarum solennia celebramus«) »or banquets (»non conuiuia «), »nor let anything pleasant in life go by« (»non quicquid in uita iucundum transmittimus $\ll) .{ }^{33}$ We might say that in the first such case he alludes to music of private devotion, and hence to the Latin-texted items published chiefly in the motet volumes but also at key positions in the song collec-

30 The letters are reprinted, with English translations by Leofranc Holford-Strevens, in Bonnie J. Blackburn, »Lorenzo de' Medici, a Lost Isaac Manuscript, and the Venetian Ambassador, « Musica Franca: Essays in Honor of Frank A. D'Accone. Festschrift series 18, ed. Irene Alm, Alyson McLamore, and Colleen Reardon (Stuyvesant, NY, 1996), pp. 33-5 and 43-4.

31 Stanley Boorman, »Did Petrucci's Concern for Accuracy Include Any Concern with Performance Issues?, "Basler Jahrbuch für Historische Musikpraxis 25 (2001), p. 37.

32 James Haar, »Petrucci as Bookman«, Venezia 1501: Petrucci e la stampa musicale. Atti del convegno internazionale di studi Venezia ... 2001, ed. Giulio Cattin and Patrizia Dalla Vecchia (Venice, 2005), p. 160.

33 The translations, here and in the ensuing paragraph are by Leofranc Holford-Strevens, as noted in connection with Blackburn, Lorenzo (cf. fn. 30). 
tions; that in the second and third he exemplifies contrasting occasions of ceremony for which the contents of the mass volumes, and those of songs and motets, respectively, would be apposite; and that in the fourth he vindicates the inclusion of songs less formal in nature.

Petrucci offers not a hint of any correlation between these various functions and types of performing medium. He is more forthcoming, however, about the reason for systematically suppressing all vernacular text beyond identifying incipits, claiming »that the Latin name, and above all Venice, where these things had been invented and perfected, should flit on men's mouths even for this modest glory of my discovery« (»latinum uero nomen et Venetum imprimis: ubi haec parta et perfecta forent: hac quoque nostri inuenti gloriola uirum uolitare per ora «). The message seems plain: it is through the promotion of Latin that Petrucci seeks to vindicate his innovative technology. It is this - together with a systematic focus on imported international compositions, initially to the virtual exclusion of anything local - that provides the most effective means of promulgating the name of Venice abroad. Consequently he underlays Latin texts to the music whenever they are available, even when this results in the provision of words that are incomplete or garbled. ${ }^{34}$ Those in other languages he discards as surplus to the enterprise's requirements. In due course, the publication of Italian frottole and other kinds of native music would follow - prolifically - but only after the project had been safely launched.

Once again there is nothing here to suggest the expectation of a link between textlessness and instrumental performance, contrary to what much of the applicable Petrucci literature over the past eighty years seems to assert or imply. ${ }^{35}$ Music for specific instruments would be taken care of eventually with the Spinacino lute prints of $1507^{36}$ and such like. The volumes that flowed from his press in the meantime had a set of purposes that lay altogether beyond such mundane considerations.

34 See Boorman, Did Petrucci's Concern (cf. fn. 31), pp. 27-9 and 31.

35 Beginning with Maurice Cauchie, »L'Odhecaton, recueil de musique instrumentale, « Revue de musicologie 6 (1925), pp. 148-56. Among recent reaffirmations of this view (though one tinged with just a hint of unease?) is that of David Fallows: »Plainly these songs were used in Italy by Italian musicians as instrumental pieces, whether or not that seems an adequate musical response to words of such delicacy. Petrucci was just continuing an established pattern.«(»Petrucci's Canti Volumes: Scope and Repertory, «asler Jabrbuch für Historische Musikpraxis 25, 2001, p. 49).

36 [Francesco Spinacino], Intabolatura de lauto libro primo [secondo] (Venice, 1507), RISM $1507^{5}$ and $1507^{6}$. 


\section{German}

While Agricola's music did not circulate extensively elsewhere in Europe during his lifetime, a few compositions travelled to Germany quite early on. They appear more often than not as contrafacta in repositories that comprise chiefly sacred texted music, with German-texted pieces and the occasional textless item mixed in. ${ }^{37}$ The obsession with exclusively foreign repertories, noted in so many Italian collections, is altogether lacking. ${ }^{38}$

Surviving German collections copied systematically without texts begin perhaps in the 1510s, by which time the custom was just about defunct in Italy. One such is the almost entirely textless D-As, $2^{\circ} 142 \mathrm{a}$, containing principally German songs, but also a pair of inserted fascicles, one devoted apparently to Josquin, the other mainly (just possibly entirely) to Agricola. ${ }^{39}$ Probably from the same decade is Fridolin Sicher's collection of keyboard arrangements (CH-SGs, 530), and a wholly untexted anthology of partmusic perhaps also copied by him (CH-SGs, 461), each with five Agricola items, as well as in the latter a four-voice »Fors seulement« by Johannes Agricola, apparently Alexander's brother. ${ }^{40}$ Then there is the collection of textless bicinia prepared c. 1521-5 in the workshop of Alamire and sent probably to Raimund Fugger the elder in Augsburg (A-Wn, Mus. 18832), which includes two extracts from Agricola Masses; and D-Mbs, Mus. 260, another bicinium book, whose textless section includes further extracts from

37 For further details see the account below of how Cecus circulated. See also Strohm, Instrumentale Ensemblemusik (cf. fn. 17).

38 Edward Lerner, prompted perhaps by the early circulation of Agricola's music in Germany, noted what he perceived to be local cantus firmi as basis for speculation that Agricola resided in German-speaking lands for a period; see his »The >German< Works of Alexander Agricola, « Musical Quarterly 46 (1960), pp. 56-66. However, Wegman expresses doubts about this in his Grove account of Agricola's biography (cf. fn. 5), and the matter remains uncertain.

39 See Das Augsburger Liederbuch. Faksimile-Ausgabe ... nach dem Exemplar Sign. CIM 43 $\left(2^{\circ}\right.$ Cod. 142a) der Staats- und Stadtbibliothek Augsburg. Faksimile-Edition Augsburg 3 (Stuttgart, 1997), and the edn. by Luise Jonas, Das Augsburger Liederbuch: die Musikhandschrift $2^{\circ}$ Codex 142a der Staats- und Stadtbibliothek Augsburg: Edition und Kommentar. Berliner musikwissenschaftliche Arbeiten 21, 2 vols. (Munich, 1983). Also, regarding the inserted fascicles, Martin Staehelin, »Möglichkeiten und praktische Anwendung der Verfasserbestimmung an anonym überlieferten Kompositionen der Josquin-Zeit, " Tijdschrift van de Vereniging voor Nederlandse Muziekgeschiedenis 23 (1973), pp. 84-5.

40 See St. Galler Orgelbuch: Die Orgeltabulatur des Fridolin Sicher. Schweizerische Musikdenkmäler 8, ed. Hans Joachim Marx, with Thomas Warburton (Winterthur, 1992); facs. edn. The Songbook of Fridolin Sicher around 1515 (Sankt Gallen, Stiftsbibliothek Cod. Sang. 461), introd. David Fallows (Peer, 1996). 
an Agricola Magnificat and a Mass. Also from this period is Bernhard Rem's textless song collection A-Wn, Mus. 18810, with a single Agricola composition. ${ }^{41}$ From a little later are the mysterious three volumes of textless compositions of which only discant parts survive, thought to have been printed around 1535 by Christian Egenolff, with four Agricola chansons in volume 3, one also copied into D-HB, X.2 $;^{42}$ the manuscript additions (Si dedero included) made by Johannes Soldeke, a minister at Barth in Germany, to his partially surviving copy of Rhau's 1538 Wittenberg print, Symphoniae iucundae RISM $1538^{8}$ (D-GRu, BW 640/1); and the part-books owned by Zwickau town official Stephan Roth († 1546), with two textless chansons, both in the section evidently copied from Odhecaton. ${ }^{43}$ With the obvious exception of Sicher's keyboard book, none of these sources yield any suggestion that their compilers thought of their textless contents necessarily in terms of instrumental performance.

Now Formschneider's 1538 Trium vocum carmina, with which this article began, comes into relief. Given the quantity of its songs (exactly one hundred), their retrospective nature, and their mode of presentation, Formschneider's publisher was plainly mindful of the Odhecaton. It is appropriate at this juncture, then, to compare the Nuremberg preface with Petrucci's Venetian dedicatory letter by returning to the points made about the former at the outset. Firstly, the German emphasis on visual representation of music fits nicely with Petrucci's preoccupation with printing per se and with the beauty of the finished product. Formschneider's very name stands for craftsmanship (remember that he >cut< for Albrecht Dürer!). Secondly, both publishers thought of the music so transmitted largely on its own terms: words, far from being objects for musical expression, had for Petrucci a political value, while for Formschneider's publisher (who does not even mention

41 On the copyist's identity see David Fallows, »The Copyist Formerly Known as Lucas Wagenrieder. Bernhard Rem and his Circle, «Die Münchner Hofkapelle des 16. Jabrhunderts im europäischen Kontext. Bericht über das Symposium München ... 2004 (Munich, forthcoming) and Joshua Rifkin, »Jean Michel and >Lucas Wagenrieder<: Some New Findings, « Tijdschrift van de Koninklijke Vereniging voor Nederlandse Muziekgeschiedenis 55 (2005), pp. 113-52, esp. pp. 144-52.

42 See Nanie Bridgman, »Christian Egenolff, imprimeur de musique, «Annales musicologiques 3 (1955), pp. 77-177; Martin Staehelin, "Zum Egenolff-Diskantband der Bibliothèque Nationale in Paris, «Archiv für Musikwissenschaft 23 (1966), pp. 93-109. The latter also details the contents of D-HB, X.2.

43 D-Z, 78,3; see Howard Mayer Brown, »Music for a Town Official in Sixteenth-Century Zwickau, M Musica Antiqua Europae orientalis. Acta scientifica congressus 7 (Bydgoszcz, 1985), pp. 479-92. 
Nuremberg in his preface) they were potential distractions. Thirdly, titles and composers' names, for Petrucci, could serve to add to the international prestige value of his collections, a consideration with which Formschneider's publisher apparently had no concern. Finally, neither Petrucci nor Formschneider show the slightest interest in performance. All in all then, the explanation for textlessness proferred in Formschneider's 1538 print, while different from that implied by Petrucci in 1501, seems not so much out of line with it. On the contrary it projects a mode of thought with which Agricola himself might well have been familiar.

\section{Textless transmission across Europe}

Viewing the transmission of Agricola works from a Europe-wide perspective helps us to reach certain preliminary conclusions about the phenomenon of textlessness. Copies of works made in environments close in cultural and language terms to those of their origin tend to resemble the form in which their composers notated them in text presentation and more besides (in Agricola's case, French chansonniers from his own time, and some Flemish song collections). When such copies are made for use in a foreign environment words that do not travel may be systematically or partially suppressed. The number of extant Agricola sources in this category is small, but at the time the quantity of such materials carried or sent around Europe - more often than not in the form of sheets and fascicles - must have been enormous. ${ }^{44}$ Such informal copies, we may surmise, could be with or without their original words according to perceived purpose at time of copying. As copies become more distant from their archetypes - in time or in terms of cultural and language separation - the perceived need for the original words weakens. Vernacular texts, in particular, may be dropped even within their own language areas (late French transmission of Agricola chansons). Beyond such areas they may sometimes still be copied, though generally in bowdlerized form (some Italian chansonniers), but are more often displaced by substitute words appropriate to local use, or simply jettisoned (several Italian sources, and virtually all the German ones).

While untexted pieces in the sources include some that surely must have been composed with instrumentalists chiefly in mind, and while, as we shall see, there is no doubt that some such players could and did play sfigured

44 Various contemporary documents refer to the dispatch by post of sheets containing individual musical works and their use in rehearsal; see, for example, the recently discovered Ambrogio Angeni letters discussed in Wilson, Heinrich Isaac (cf. fn. 21). 
polyphonic music (especially from around 1480), the fact remains that there is little or no evidence to connect any of the sources that characteristically transmit songs without their words directly with instrumental performance, save in the case of dedicated intabulations. In the circumstances the instrumental assumption commonly advanced for untexted compositions in polyphonic sources (Italian or otherwise) does begin to look simplistic. And it sits unhappily with the view, alluded to above, that textless voices in fourteenth- and fifteenth-century polyphony both sacred and profane generally connote vocalization rather than instrumental performance. At least it seems inadequate as explanation for how Agricola and his contemporaries themselves perceived music, either in terms of sound and its notation, or of the multifarious purposes the surviving manuscripts and prints may have served.

In any event, alternative approaches are possible. In a recently published article I rehearse the thesis that, for Agricola and his contemporaries, words serve as point of departure for music that in both sound and notation is valued not so much as vehicle for their projection as for its own intrinsic worth. ${ }^{45}$ They may leave their mark on the music - sometimes, indeed, with stunning expressive effect. However, there is no a priori rule that they have to, since they are not yet conceptualized as part of a work's essence as they would come to be within half a century of Agricola's death. Such approach to the ontology of the work vindicates not only the well-known casualness with which music scribes from Agricola's time (even those geographically and linguistically close to him) generally present words, but also the practice, especially prominent in sources more remote from their composers, of presenting certain kinds of song (vernacular especially, but not excluding song-like Latin devotional works) with their originally envisaged words set out only partially or not at all.

It also helps explain why there is no sign that Agricola and his contemporaries distinguished vocal from instrumental music either along repertorial lines or in terms of whether or not words are present. Adam von Fulda - in 1490 apparently one of the earliest writers to articulate a distinction of any kind - does little more than state the obvious when observing of »musica artificialis « (composed music, as opposed to improvised), »hoc genus tenent musici. Est vel instrumentalis vel vocalis. Instrumentalis est sonus per diversa instrumenta causatus, qui cum sit vocalis, tamen eius voces sunt materiales.« (»This kind of music is practised by musicians. It is either

45 Warwick Edwards, »Agricola and Intuitive Syllable Deployment, «Early Music 34 (2006), pp. $409-26$. 
instrumental or vocal. Instrumental [music] is the sound caused by various instruments; although it has voices, yet its voices are material.« ${ }^{46}$ Adam, of course, is here dealing with »music « in the sense his readers would have expected: of its sounds. Yet he could scarcely have gone further to characterize musical »works - a concept still in process of formulation - in terms of their innate vocality or instrumentality, even if it had occurred to him to do so. For the very possibility that words can be viewed as ancillary to the essential musical work casts doubt as to whether one can make any clear-cut distinction between music conceived wholly or partially for words and that conceived without.

\section{The performing traditions}

Still, Adam von Fulda at least acknowledges a material distinction between voices and instruments. Moreover, from contemporary documentation it seems pretty clear that singers and instrumentalists tend to operate within performing traditions that are in many respects separate, even though they may share certain kinds of repertory. It is with the relationship to these traditions of Agricola's compositions as he himself conceived them that the rest of this essay is concerned. We shall need to consider first the performance of songs for which setting words seems to have formed a point of compositional departure, along with those built on pre-existent chants or other monophonic tunes that are readily identified with their own built-in words. We may then turn to songs that appear to have been constructed largely without reference to words at all.

\section{Songs conceived with words}

The exact extent of the former categories - his songs with words - cannot be identified with complete confidence. That is simply because many such songs survive only in wordless form - sometimes alongside songs originally without words that have picked up contrafact texts - in sources that were prepared in or for locations distant from the environment that produced the song in the first place. Nevertheless the canon can be reasonably well cir-

46 »Adami de Fulda Musica«, as printed in Martin Gerbert, Scriptores ecclesiastici de musica sacra (St. Blasien, 1784, Reprint Hildesheim, 1963), vol. 3, p. 333 (the original Strasbourg manuscript was burnt in 1870). My thanks again to Leofranc Holford-Strevens for the English translation. 
cumscribed by judicious reference to what appears in texted sources, to alternative sources of words indicated by text incipits or associated with known tune citations, and to pieces that, while wordless in the sources, show comparable characteristics of musical phrasing and articulation.

We have already noted the likelihood that long-standing traditions of a cappella singing continue to characterize performances of vernacular song and Latin devotional music alike, at least in the immediate environments in which northern composers such as Agricola worked. Since such vocal traditions are apparently compatible with the presence of untexted voice-parts there seems little reason to doubt their applicability in cases where Agricola seems to have made only limited provision for words even in top parts. This is especially true of compositions entailing use of a pre-existent monophonic chant or popular tune. In the case of works that combine one text in a cantus firmus with a different (though generally related) one elsewhere in the counterpoint the musical scheme (and sometimes symbolic considerations) tends to undermine the music's responsiveness to the cyclic refrain structure demanded by the words and to dilute the extent to which words in top or other voices shape the melodic line. This tends to happen especially in Agricola's so-called chanson motets. »Belles sur toutes« / $\gg$ Tota pulchra es«, for example (one of the six Agricola items to appear posthumously in the Trium vocum carmina), is transmitted in four earlier music sources, all relatively distant from Agricola, none of which transmit the French words. ${ }^{47}$ However, a poetry source (F-Pn, fr. 1722) provides the ten-syllable rondeau quatrain likely to be the poem indicated by the incipit because of cross references to the words of Latin antiphon tenor. Here the French verses serve as symbolic accretions in a musical composition sprung from its preexistent chant tenor, rather than as objects whose several syllables are to be $>$ set $<$ in premeditated fixed positions. ${ }^{48}$

Where the words of a cantus firmus seem to be those for the song as a whole it may often be said that Agricola sets the tune rather than its words. A notable example among his Latin devotional compositions is his »Si dedero« (another one of the Formschneider six). Here the chant for a responsory verse is embellished in two of three voices in a manner that is compatible with long-standing a cappella performance traditions associated with polyphonic chant setting for liturgical purposes. At the same time

47 Canti C (1504), I-Fc, Basevi 2439, CH-SGs, 462, GB-Lbl, Add. 31922.

48 Lerner in his transcription takes little or no account of the hemistich structure, and prints »seul« for »seulle« in line 3, leaving it a syllable short; I am grateful to Kate Maxwell for checking the text of the poem direct with its unique source. 
Agricola's approach here to three-voice composition is in effect not only wordless but sufficiently idiosyncratic to have inspired a number of musical responses by his contemporaries whose titles simply refer to its opening two words, all of them capable of vocal or instrumental performance, notwithstanding the variable roles that words had to play in their conception. ${ }^{49}$

Much the same may be said of settings built around tunes of so-called >popular< cast. In In mijnen sin, for example, Agricola's preoccupation with the tune is such that he seems to require its associated words to be adapted to the musical development as it unfolds, rather than the other way round. ${ }^{50}$ Admittedly, some of his popular tune settings entail the kind of syllabic glove-fit that makes a cappella vocal performance seem inevitable (e.g. »Par ung jour de matinee «). But many do not. In the »Adieu m'amour « setting uniquely found in I-Fc, Basevi $2439,{ }^{51}$ for example, Agricola composes counter-melodies to the tune quoted in the tenor in ways that manifestly have little or no regard for word placement. Yet, as argued above, we cannot lightly set aside the possibility of all-vocal performance on that ground alone. Popular melodies, after all, seem to have flourished in the context of polyphony first of all in the combinative chanson repertories of Antoine Busnoys and - of special significance for Agricola - Ockeghem. Many such compositions are notable too for a loose relationship between words and the melodies to which their syllables are to be deployed. Yet that is no argument for the idea that they are necessarily instrumental. What copyists seem to imply in all these instances is that, at least within the cultural environments for which they are conceived, singers may employ words complete, selectively or not at all, according to perceived requirements of musical articulation.

What of performance traditions in which instruments participate alongside voices? Among the more telling instances of what seems to be a newly emerging trend towards instrumental participation in composed polyphony are those involving the German Augustin Schubinger. Having served as a trombonist with various German employers, including Friedrich III and Maximilian I, as well as in the civic ensemble of Florence, Schubinger was

49 See further the discussion, and music example showing comparative syllable deployments in the six texted sources, in my Agricola (cf. fn. 45), pp. 409-12. On the relationships between the several pieces with titles or text incipits beginning » $\mathrm{Si}$ « that Agricola's composition seems to have catalysed see Meconi, Sacred Tricinia (cf. fn. 15), pp. 173 onwards.

50 Edwards, Agricola (cf. fn. 45), pp. 409-13.

51 Alexandri Agricola Opera omnia. Corpus Mensurabilis Musicae 22, ed. Edward R. Lerner, vol. 5: Cantiones, Musica Instrumentalis, Opera dubia (American Institute of Musicocogy, 1970), no. 26, pp. 44-5. 
engaged as part of Philip the Fair's entourage in November 1500 just three months after Agricola had joined his chapel. ${ }^{52}$ During the following year he is paid for playing cornetto at high mass in Mechelen (»Gegeven Meester Augustin van dat hy speeld ter hoo[g]missen $\ll) .{ }^{53}$ The same happens at Pentecost 1502 in Toledo when King Ferdinand's and Duke Philip's singers join to sing different parts of the Mass successively. ${ }^{54}$ And again on Easter Day 1503, apparently at Lausanne, with the choirs of Savoy and HabsburgBurgundy. ${ }^{55}$ Finally, in September of that year Schubinger is presumably still among Philip's entourage when the grande chapelle joins with that of his father in Innsbruck to celebrate mass, although on this occasion it was the »sackbuts of the King [Maximilian, who] began the Gradual, and played for the Deo gratias and Ite misa est $\ll{ }^{56}$ Such practices in the performance of sacred music evidently spread in subsequent years, though it seems they were not reflected in notated musical sources until Girolamo Scotto's 1539 Venice publication of Nicolas Gombert's four-voice motets, in a set of parts designated apt for string and wind instruments (»Lyris maioribus, ac Tibijs imparibus accommodata $\ll)^{57}$

Meanwhile one assumes that the shift towards instrumental participation in composed polyphony began to manifest itself at around this time in

52 Keith Polk, »The Schubingers of Augsburg: Innovation in Renaissance Instrumental Music, "Quaestiones in musica: Festschrift für Franz Krantwurst, ed. Friedhelm Brusniak and Horst Leuchtmann (Tutzing, 1989), pp. 495-503; Edmond Vander Straeten, La musique au Pays-Bas avant le XIX e siècle, vol. 7 (Brussels, 1885), p. 172.

53 Polk, The Schubingers, ibid., p. 501, and Keith Polk, »Instrumental Music in Brussels in the Early $16^{\text {th }}$ Century, « Revue belge de musicologie 55 (2001), pp. 93-4.

54 Louis Prosper Gachard, Collection des voyages des souverains des Pays-Bas, vol. 1: Itinéraires de Philippe le Hardi, Jean Sans Peur [etc.] (Brussels, 1876), p. 178, after the Burgundian court chronicler Antoine de Lalaing. As it happens, Agricola appears to be on leave of absence on this particular occasion (see Meconi, Pierre de la Rue and Musical Life, cf. fn. 9, p. 70).

55 Gachard, Collection, ibid., p. 287, again after Lalaing whose reference to location is here ambiguous. See also Martin Picker, The Chanson Albums of Marguerite of Austria: MSS 228 and 11239 of the Bibliothèque Royale de Belgique, Brussels (Berkeley, 1965), p. 24, and Meconi, Pierre de la Rue and Musical Life (cf. fn. 9), p. 35, both citing Gachard but locating the event at »Villars-en-Bresse« (Villars les Dombes?) and Bourg-en-Bresse, respectively.

56 Polk, Instrumental Music (cf. fn. 53), p. 94. Polk notes further instances from around 1500 of instrumentalists playing with choirs in sacred services - some more conclusive than others - in his »Instrumental Music in the Low Countries in the Fifteenth Century, « From Ciconia to Sweelinck. Donum natalicium Willem Elders. Chloe 21, ed. Albert Clement and Eric Jas (Amsterdam, 1994), p. 29.

57 RISM G 2977. See Richard Sherr, »Questions concerning Instrumental Ensemble Music in Sacred Contexts in the Early Sixteenth Century, " Le concert des voix (cf. fn. 29), pp. 149-50. 
vernacular song too. Again, the evidence is patchy, while documentation applicable to Agricola's immediate environment seems to be altogether lacking. ${ }^{58}$ Among the earliest instances of such song notated expressly for voice and instrument together would appear to be the Petrucci Franciscus Bossinensis prints of 1509 and 1511, with their frottola arrangements for voice and lute, aimed at a market far removed from Agricola's world. ${ }^{59}$

The performance of composed vernacular songs and Latin devotional music by solo instruments is demonstrable long before Agricola's time by the existence of tablatures, notably the Italian Faenza and German Buxheim manuscripts. As it happens no such Agricola sources survive from his lifetime, though, as noted above, several of his compositions appeared the year after his death in the 1507 Petrucci-Spinacino lute prints, and some years later in the Sicher keyboard manuscript and in the second of Hans Neusidler's two lute prints of $1536 .^{60}$

Without doubt, instrumental ensembles too performed notated polyphony in Agricola's time. Keith Polk notes that $\gg$ in such cities as Bruges, Kampen and Utrecht, accounts which describe [evening Lof] performances specify not only that the players performed >motets<, but, further that composed pieces (>gezette stucken $<$ ) were involved. $\aleph^{61} \mathrm{He}$ also calls attention to a record of »the minstrels of the city of Brussels « performing in 1495 at the table of Philip the Fair "plusieurs chanssons de musicque ${ }^{62}$ The link between such performance traditions and notated music becomes strikingly explicit in the case of two letters from the Venetian trombonist Giovanni Alvise Trombon to Francesco Gonzaga. The first, datable towards the end of December 1494, informs us that

In questi zorni pasadi nui avemo posto zerti moteti innordine per sonar, dei quali do ne mando a la Signoria Vostra. Et l'uno de quei si è hopera de Hobert, zoè le quarto voze, do sovrani et uno tenor et uno contra alto; et perchè siamo sei li ò azonte do voxe base per sonar chon i tromboni che viene

58 See Wright, Voices (cf. fn. 8); Fallows, Specific Information (cf. fn. 8), pp. 131-44; Keith Polk, »Voices and Instruments: Soloists and Ensembles in the $15^{\text {th }}$ Century, Early Music 18 (1990), pp. 179-98.

59 Tenori e contrabassi intabulati col sopran in canto figurato per cantar e sonar col lauto Libro primo [secundo] (Venice, 1509 and 1511), RISM $1509^{3}$ and 1511.

60 Hans Newsidler, Ein newgeordent künstlich Lautenbuch (Nuremberg, 1536), RISM $1536^{13}$, part 2.

61 Polk, Instrumental Music (cf. fn. 53), p. 100. The reference to »gezette stucken« is from a directive to the players of Kampen dated 1483; see Keith Polk, German Instrumental Music of the Late Middle Ages: Player, Patrons and Performance Practice (Cambridge, 1992), p. 122.

62 Ibid., citing Georges Van Doorslaer, »La chapelle musicale de Philippe le Beau, «evue belge d'archéologie et d'histoire de l'art 4 (1934), p. 140. 
a esser a voxe sei et fa un bon aldir e chi'l volese sonar anche a zinque voxe, li ò fato anche un altro chontra baso da parte de quei do, dapoi vi mando. Anche un altro moteto »Dimandase Gabrielem«: è de hopera de Busnojs; zoè le quatro voxe et io li ò fato un altro contra baso che el soniamo a zinque, che in verità tuta Venezia non vol audir altro. ${ }^{63}$

In these past days we have made instrumental arrangements of certain motets, of which I am sending two to your Lordship. One of these is a work of Obrecht, that is, in four voices, two sopranos, a tenor, and a »contra alto [bassus]. And because we are six, I have added two bass parts to be played by trombones. This totals six parts and makes a good piece; and if one wants to play it in five parts, I have made another bass »contra alto from these two. I am also sending you a further motet, »Dimandasse Gabrielem«; it is by Busnoys and is for four voices. I have done another bass »contra« because we play it in five [parts], and, to tell the truth, all Venice wants to hear nothing else. ${ }^{64}$

The second, dated 27 July 1505, conveys the following:

Saverà la Signoria Vostra come in quell tenpo fossemo a Mantoa, el segnor Don Alfonso, ducha de Ferara, voleva invenir de oldir 4 tronboni et 2 cornetj, e mai ne ebe gratia per non aver le cosse aparechiate et ordenate et chi le abj sapute far, onde dapoi iunsij a Venetia mj misj al forte et ho trovato la vera via de quele et de più bele alter cosse et hole sperimentade tute; zoè tronbonj 4 , cornetj 2 , et poi tronbonj 4 e pifarj 4 , et poj quell medemo moteto a fiautj 8 , et più vj mando per sonar con tronboni 5 in una bota, et più mando uno pezo che se sona a zinque. Onde, trovandomi al prexente in leto amalado in suma nezesità et dubitando de la vita mia, ho voluto mandarlj a la Signoria Vostra aziò quelj restan in le mani vostre, zertificando la Signoria Vostra che né mj né altri à copia de tal cosse. ${ }^{65}$

Your Lordship will know that, during the time we were in Mantua, Don Alfonso, duke of Ferrara, wanted to hear four trombones and two cornetti, and he was never able to do so because the pieces were not arranged [for this combination] and there was no one who knew how to make them. For this reason, when I returned to Venice, I put myself to the task and have found the way to do these and other beautiful things as well, and I have tried them all out: that is, four trombones and two cornetti, and also four trombones and four shawms, and also the same motet for eight recorders, and I am sending you a dialogue to play with five trombones, and also I am sending a piece that is played $a 5$. At present, I find myself sick in bed in great need and

63 William Prizer, $»$ La cappella di Francesco II Gonzaga e la musica sacra a Mantova nel primo ventennio del Cinquecento, « Mantova e $i$ Gonzaga nella civiltà del rinascimento. Atti del convegno ... Mantova ... 1974 (Mantua, 1977), p. 274, citing Mantua, Archivio di Stato, B. 1435 , fol. 574 .

64 Prizer, Instrumental Music (cf. fn. 29), p. 185.

65 William Prizer, »Bernardino Piffaro e i pifferi e i tromboni di Mantova: strumenti a fiato in una corte italiana, « Revista italiana di musicologia 16 (1981), pp. 182-3, citing Mantua, Archivio di Stato, B. 1441, fol. 132. 
fear for my life, and so I wanted to send these [pieces] to your Lordship so that they would be in your hands, certifying to your Lordship that neither I nor anyone else has copies of such things. ${ }^{66}$

Admittedly these letters emanate from an environment different from that in which Agricola must have conceived most of his works. However, the earlier was written not long after Agricola's first recorded year-long foray into Italy (1491-2), and possibly contemporaneously with his second sojourn in Naples to which he returned in 1494 (it is not known when he left). And it is precisely during these periods that Agricola might well have fashioned his six-voice setting - uniquely transmitted in D-As, $2^{\circ} 142 \mathrm{a}$ - of the originally three-voice Italian canzona »Fortuna desperata «, apparently in much the same spirit as Alvise had in mind.

\section{Songs without words: 1 . The freely-composed works}

The link between instruments and composed polyphonic music conceived with words is incontrovertible in some of the documented instances discussed above. This might seem to vindicate the idea that, generally speaking, songs conceived without words are simply instrumental works. Implicit in this, however, is the assumption that such compositions are linked to a developing musical >literacy< among instrumentalists. The supposed link is not without its problems, among them the manner in which collections of instrumental tablatures continue to focus overwhelmingly on arrangements, and the awkward fact, noted by Litterick, that putative »instrumental« music from Agricola's time seems to leave no lasting compositional legacy ${ }^{67}$

Among the most discussed of Agricola's songs supposedly conceived without words is that generally known under the title Cecus non judicat de coloribus (»The blind man does not judge about colours«), though in fact it circulated with several different Latin texts or incipits. Agricola's authorship, while likely on stylistic grounds, is contradicted in two relatively early manuscripts, and indeed is indicated only in selected sources compiled after his death. Possibly the earliest source of all to transmit the work is a recently recognized bifolium with untitled and unascribed sections of the tenor and

66 Prizer, Instrumental Music (cf. fn. 29), pp. 185-6.

67 Litterick, On Italian Instrumental Ensemble Music (cf. fn. 19), pp. 128-30. See also Carl F. Jickeli, Textlose Kompositionen um 1500. Europäische Hochschulschriften 36.119 (Frankfurt/M., 1994), p. 186 (»Die textlosen Sätze um 1500 können demnach nicht als frühe >instrumentale< Kompositionen aufgefaßt werden, sie stellen vielmehr die Spätstufe einer langen Tradition dar $\ll$ ). 
bassus of the secunda pars.$^{68}$ It is one of a series of fragments removed from the covers of journals of, and of books printed by, the Antwerp firm of Plantin-Moretus, and likely therefore to be of local origin. ${ }^{69}$ With the antiphon incipit »Gaudent in celis « the work was copied, apparently in the early 1480s, into the earliest layer of Nicolaus Leopold's Innsbruck choirbook (D-Mbs, Mus. 3154). ${ }^{70}$ By the end of the century it had also been copied into the possibly Silesian collection D-B, Mus. $40021,{ }^{71}$ and the secunda pars into Nikolaus Apel's choirbook (D-LEu, 1494) ${ }^{72}$ in both instances drawing on the same text beginning $\gg$ Regali quam decet«. Probably at much the same time it was copied into the Bohemian CZ-HK, II A 7 (Speciálnik), now with an unlikely ascription to Isaac, and with words beginning »Ave ancilla trinitatis «. At around the turn of the century it appears in the Segovia Manuscript, apparently copied in Spain by a Flemish-speaking scribe, with superius and contratenor bearing the incipit Cecus non judicat de coloribus (as above), and tenor Cecus non judicat de valoribus (»The blind man does not judge about [?notated musical] values«). The whole piece is headed - in the space usually allotted in this source to composer ascriptions $-\gg$ Ferdinandus et frater ejus «. At about the same time it was copied anonymously, and with the heading Cecus, into the Florentine manuscript I-Bc, Q 17. At some point between February 1512 and August 1514 Johannes Heer, a Paristrained clergyman in Glarus, Switzerland, copied it into his songbook (now $\mathrm{CH}-\mathrm{SGs}$, 462) without title, but with ascription to $»$ Alexander ${ }^{73}$ And

68 B-Amp, M 6, fol. 7, reproduced in Anthologie van muziekfragmenten wit de Lage Landen (middeleeuwen - renaissance). Polyfonie, monodie en leisteenfragmenten in facsimile, ed. Eugeen Schreurs (Peer, 1995), pp. 68-9, the Cecus fragment on fol. $7 \mathrm{~b}^{\mathrm{r}}$ being identified subsequently by David Fallows and quoted in Jacobijn Kiel, »The Antwerp Fragments $M$ 6, Music Fragments and Manuscripts in the Low Countries. Yearbook of the Alamire Foundation 2 (Peer, 1997), pp. 45-51.

69 Jaap van Benthem, »The Alamire Fragments of the Plantin-Moretus Museum in Antwerp, « Musicology and Archival Research. Colloquium Proceedings Brussels ... 1993. Archives et bibliothèques de Belgique 46, ed. Barbara Haggh, Frank Daelemans and André Vanrie (Brussels, 1994), pp. 542-57.

70 Edited in Der Kodex des Magister Nicolaus Leopold, Erster Teil. Das Erbe deutscher Musik 80, ed. Thomas L. Noblitt (Kassel, 1987), no. 51, pp. 241-9. On copying dates for this section of the manuscript see Rifkin, Munich, Milan (cf. fn. 25), pp. 284-307.

71 Edited in Der Kodex Berlin 40021, Erster Teil. Das Erbe deutscher Musik 76, ed. Martin Just (Kassel, 1990), no. 17, pp. 141-8.

72 Edited in Der Mensuralkodex des Nikolaus Apel, Zweiter Teil. Das Erbe deutscher Musik 33, ed. Rudolf Gerber (Kassel, 1960), no. 124, pp. 225-7.

73 For an edition of the manuscript and discussion of its copyist see Das Liederbuch des Johannes Heer von Glarus. Ein Musikheft aus der Zeit des Humanismus (Codex 462 der Stiftsbibliothek St. Gallen). Schweizerische Musikdenkmäler 5, ed. Arnold Geering (Basel, 
during the period c.1512-21 Swiss organist and composer Fridolin Sicher copied it into his keyboard book (CH-SGs, 530) with the title Diva parens. Finally it appeared in two Nuremberg prints: set for lute without title, but with ascription to Alexander Agricola, in Neusidler's Der ander theil des Lautenbuchs (1536), and anonymously in Formschneider's Trium vocum carmina (1538), but with handwritten title Cecorum and ascription to Alexander Agricola added by the owner of the Jena copy. ${ }^{74}$

Reinhard Strohm proposed that the Segovia Manuscript's »Ferdinandus and his brother « were the blind Jehan and Charles Fernandes of Bruges who held appointments in the teaching of letters at the University of Paris from at least 1478; as organist at St Donatian's (Bruges) briefly in 1482; as instrumentalists in Charles VIII's household in 1488 and 1490; and who were surely the blind violist brothers »Johannes and Carolus« whose music Tinctoris reported hearing in Bruges in the following well-known passage from the De inventione et usu musice (c. 1482-4?): ${ }^{75}$

Neque preterire in animum venit: quod exiguo tempore lapso: duos fratres Orbos natione Flamingos: viros quidem non minus litteris eruditos quam in cantibus expertos: quorum uni Carolus: alteri Johannes nomina sunt. Brugis audiverim: illum supremam partem et hunc tenorem plurium cantilenarum: tam perite: tamque venuste hujusmodi viola consonantes: ut in ulla nunquam melodia: me profecto magis oblectaverim. Et quia rebecum (si sonitor artifex et expertus fuerit) modulos illis quam simillimos emittat: quibuslibet affectus spiritus mei (occulta quadam familiaritate) ad leticiam quam simillime excitantur. Hec itaque duo instrumenta mea sunt. mea inquam: hoc est quibus inter cetera: animus meus ad affectum pietatis assurgit: quaeque ad contemplationem gaudiorum supernorum: ardentissime cor meum inflammant. Quo mallem ea potius ad res sacras: et secreta animi solamina semper reservari: quam ad res prophanas et publica festa interdum applicari.

Nor does it come to mind to pass over the fact that, a little while ago, I heard two blind brothers, both Flemings, at Bruges, one of whom is called Charles

1967); facs. edn. as Das Liederbuch des Johannes Herr von Glarus. Faksimile-Edition Rara 7 (Stuttgart, 1998).

74 Howard Mayer Brown (Instrumental Music Printed Before 1600: A Bibliography, rev. reprint, Cambridge, Mass., 1967, pp. 59-62) reads »Cecox«, and implies a similar handwritten identification in the Berlin copy which I have not seen.

75 Strohm, Music (cf. fn. 12), pp. 32, 88, 143. Paula Higgins subsequently noted, from Burgundian court records of payments to them in 1468 and 1470, that the blind Jehan Fernandes who, along with Jean Cordoval, impressed Martin Le Franc by his instrumental skills in the 1430s and remained at the Burgundian court until the 1450s, was their father (review of Strohm, Music, cf. fn. 12, in Journal of the American Musicological Society 42, 1989, p. 159). See further André Pirro, »L'Enseignement de la musique aux universités françaises, «Acta musicologica 2 (1930), p. 46; Hiroyuki Minamino, »ohannes and Carolus Fernandez, Fifteenth-Century Composers of Music for Lute, « The Lute 37 (1997), pp. 5-8. 
and the other John, men who are to be sure no less scholarly in Latin letters than proficient in music, the former playing the superius and the latter the tenor of many songs, harmonizing them together as skilfully and as beautifully on a viola of this kind, so that indeed I have never delighted more in any music. And because the rebec (if the player be a craftsman and proficient) can produce melodies as similar as possible to those [of the viola], with any [melodies] my emotions are aroused, [by the rebec], through a mysterious inner kinship, to as similar a delight as possible. Accordingly these two instruments are mine, mine I say, that is to say that through these, among other things, my mind rises to a feeling of devotion, and which most ardently inflame my heart to the contemplation of heavenly joys. For this reason I would rather have them be reserved always for sacred matters, and for private solace of the mind, than sometimes used for secular matters and public festivities. $^{76}$

As others have pointed out, this passage comes from an account of performance media - voices and instruments alike - supposed to have evolved from antiquity. ${ }^{77}$ Its immediate context is an evaluation of stringed instruments, Tinctoris's chief point being the potential of the viola - and in the hands of the right musicians even the rebec - to produce sounds worthy of the status commonly attached to that of voices in the singing of sacred music. Indeed, having established the theorist's dependence on Augustine's Confessions in the formulation of his argument, Christopher Page wonders

whether Tinctoris's quotations from that book in the De inventione et usu musice give any special resonance to a note of anxiety that he sounds about the pleasure, both aesthetic and intellectual, that he enjoyed when he heard the two string players in Bruges play secular pieces. Tinctoris's wish that the viola and rebec, which so ravished him on that occasion, be reserved »for sacred matters and for private solace« and not used »for secular matters and public festivities « amounts to a censure of the very occasion which so delighted him. ${ }^{78}$

Exactly what Tinctoris heard the Fernandes brothers play is unknowable. Nor indeed can it be determined when his encounter took place or when he wrote about it. ${ }^{79}$ Still, it is not hard to imagine $»$ Cecus« acquiring its apho-

76 Transcription and translation from Christopher Page, »Reading and Reminiscence: Tinctoris on the Beauty of Music, "Journal of the American Musicological Society 49 (1996), p. 11.

77 Anthony Baines, »Fifteenth-Century Instruments in Tinctoris's >De Inventione et Usu Musicae<, «alpin Society Journal 3 (1950), p. 19.

78 Page, Reading (cf. fn. 76), p. 30.

79 Tinctoris, it seems, may well have interrupted his residence at the Naples court between the early 1470s and ? 1487 with one or more trips abroad. However, I can find no basis for Strohm's dating of his Bruges experience to 1482 (Strohm, Music, cf. fn. 12, p. 143) or »probably in 1482« (Reinhard Strohm, The Rise of European Music, 1380-1500, Cambridge, 1993, p. 366). I am grateful to Ronald Woodley for advice on the uncertain state of our knowledge about Tinctoris's travels. 
ristic title by virtue of the assimilation of its top and tenor voices into the brothers' repertory at some stage. ${ }^{80}$ Strohm believed so, but took the work to have originated as a motet, »Gaudent in celis « ${ }^{81}$ Most, however, regard it as of instrumental conception on account of its prominent »sequential and motivic patterning, passage-work, pedal-points, and ostinatos « ${ }^{82}$ Polk, viewing Cecus as the (partly improvised?) work of »Johannes and Carolus Fernandes [or Alexander Agricola] « (his brackets) saw such features as indications of how "players may have created free sections spontaneously $\ll .{ }^{83}$ However, as most commentators admit (myself included), such devices are just as often encountered in vocal music, especially masses and motets. ${ }^{84}$ Moreover it is far from self-evident that they epitomize improvisation practices. ${ }^{85}$ Given what we know of the Fernandes' careers, it is more likely that they represent something of an intellectual approach to making music, imbued in some respects with reminiscences of the classroom. Dietrich Kämper, noting the pedagogic overtones of »coloribus« and »valoribus« in the Segovia Manuscript ascriptions, called attention to the use in the tenor of the hexachord scale in successively expanding form in a manner redolent of what every singer of polyphony had to learn. ${ }^{86}$ As motet cantus firmus the device was also used, perhaps contemporaneously, by Isaac (»O decus ecclesie «), and later by Josquin (»Ut Phebe radiis«). The idea of organic expansion had also been applied in more supple and interesting ways to other kinds of motif in vocal compositions by Busnoys, and would be exploited with particular effect by Obrecht, as Wegman showed. ${ }^{87}$

All this tends to confirm that the vocal-instrumental dichotomy, lying outside the conceptual framework of the period, is a false one. Seen in that

80 On related expressions in Aristotle and in the thirteenth century see Page, Reading (cf. fn. 76), p. 12.

81 Strohm, The Rise (cf. fn. 79), p. 366.

82 Howard Mayer Brown and Keith Polk, »Instrumental music, c. 1300 - c. 1520, « Music as Concept and Practice in the Late Middle Ages. The New Oxford History of Music 3.1, ed. Reinhard Strohm and Bonnie J. Blackburn (Oxford, 2001), p. 130. Of course it is possible that the title »Gaudent in celis« (»They rejoice in heaven«) in D-Mbs, Mus. 3154 was also intended as an aphorism, rather than as incipit for an antiphon text.

83 Polk, German Instrumental Music (cf. fn. 61), pp. 155-7.

84 See, for example, Brown and Polk, Instrumental Music (cf. fn. 82), p. 130; as well as my »Songs Without Words by Josquin and his Contemporaries, « in Music in Medieval and Early Modern Europe (cf. fn. 19), p. 81.

85 See Litterick's cautionary note in On Italian Instrumental Ensemble Music (cf. fn. 19), p. 129.

86 Dietrich Kämper, »Instrumentale Stilelemente bei Alexander Agricola, «Tijdschrift van de Vereniging voor Nederlandse Muziekgeschiedenis 28 (1978), p. 10.

87 Wegman, Born (cf. fn. 12), pp. 179-81. 
light the Segovia ascription to the Fernandes brothers might signify not so much the composers of a completed instrumental work $<$ as the exponents of a performance process whose distinctiveness transcends that of any putative instrumental-vocal divide. It is easy to imagine a young and receptive Agricola susceptible to a sense of play observing the techniques the blind instrumentalists deployed to sustain their performances and turning them to fertile use in what, regardless of performing medium, amounts to a veritable compendium of devices the Fernandes famously used to sustain their improvisations.

A similar context may be applicable to some further Agricola compositions that lack cantus firmi and sound like >songs without words<, yet cannot with confidence be identified with any particular long-standing instrumental performance tradition. Pater meus agricola est, with its punning allusion to Agricola's none too illustrious father, ${ }^{88}$ was far less well circulated than Cecus,${ }^{89}$ but shares with it some of its constructivist devices (the »expanding hexachord « included). With its enigmatic Latin title and cryptic selfgenerated tenor, the Ut heremita solus in Petrucci's Motetti C (Venice, 1504), RISM 1504', and Hermann Finck's Practica musica (Wittenberg, 1556) might be another such work, if Andrea Lindmayr-Brandl is right in proposing it as an Agricola composition, linked in some way with Ockeghem, as the poet Guillaume Crétin implies. ${ }^{90}$ By comparison with these, Oblier veult douleur et tristesse (another Trium vocum carminum item) was quite well circulated, though never with any more words than that, even in the otherwise fully texted collection of six chansons in the French manuscript F-Pn, fr. 1596 of c. $1500 .{ }^{91}$ One wonders if this incipit too is an aphorism. The work does not sound like a chanson. Some kind of pre-existent musical material seems to be present. Could the latter half feature a pair of solmization mottoes? La sol la fa mi, and Fa mi sol sol la or Fa mi sol la - the latter standing for $\gg$ Agricola $\ll$ ?

88 Rob C. Wegman, »>Pater meus agricola est $<$ The Early Years of Alexander Agricola,« Early Music 34 (2006), pp. 375-89.

89 The work is known only through Petrucci's Motetti libro quarto (Venice, 1505), RISM $1505^{2}$, and Sebald Heyden's, De arte canendi (Nuremberg, 1540).

90 Andrea Lindmayr-Brandl, »Ockeghem's motets: Style as an Indicator of Authorship: The Case of >Ut heremita solus< Reconsidered", Johannes Ockeghem: Actes du XLe Colloque International d'Études Humanistes, Tours ... 1997, ed. Philippe Vendrix (Paris, 1998), pp. $499-520$.

91 On this manuscript see Richard Wexler, »Music and Poetry in Renaissance Cognac, « Le Moyen français 5 (1979), pp. 102-14. 
Songs without words: 2 . Settings of wordless tenors

If in the >freely-composed songs without words Agricola draws on selected techniques characteristic of notationless improvised instrumental performance tradition, in those built on wordless tenors he engages with the underlying processes that characterize such performances. Singers and instrumentalists alike in his time commonly made polyphony by improvising $»$ discants« and »contratenors « around pre-set melodies sung or played by a »tenorista $\ll .{ }^{92}$ The practice is plainly implied in notated musical sources that present only tenors. Of these, best known are two closely interrelated dance manuals, the late-fifteenth-century Burgundian basse-danse manuscript, B-Br, 9085, and Michel de Toulouze's print entitled L'art et instruction de bien dancer (Paris, [1496 or earlier]). Mostly comprising undifferentiated breves, the tenors in these dance books are carefully set out to supply the correct number of notes and »measures « for each individual choreography (Beaulté, for example, the first tenor in the manuscript collection, and the $26^{\text {th }}$ in the print, is designated in both sources $\gg$ a xxxix notes a. iiii. mesures«). From the colophon in the print it is clear that they are to be played by instrumentalists: »Avecques celles regles [de dancer] sont notes pour Jouer a tous Instrumens nouvellement imprimees ${ }^{93}$

Much has been written about the bands, both baut and bas, that played such music, and the manner in which they improvised counterpoints on preexistent tenors. ${ }^{94}$ But such instrumental ensembles surely played more than just dance music. Many of the tenors in these, and other sources of similar repertory, derive from, or are otherwise related to, individual voice parts in

92 On the role of a tenorista as linchpin in the direction of polyphony, both composed and extemporized, see Rob C. Wegman, »From Maker to Composer: Improvisation and Musical Authorship in the Low Countries, 1450-1500, "Journal of the American Musicological Society 49 (1996), esp. pp. 444-9.

93 For facsimiles of the two sources see Le manuscrit dit des Basses danses de la Bibliothèque de Bourgogne, ed. Ernest Closson (Brussels, 1912, Reprint Geneva, 1976); Les basses danses de Margueite d'Autriche. Vollständige Faksimile-Ausgabe im Originalformat der Handschrift MS 9085 aus dem Besitz der Bibliothèque Royale Albert I., Bruxelles, 2 vols. (Graz, 1988); L'art et instruction de bien dancer, ed. Victor Scholderer (London, 1936); and S'ensuit l'art et instruction de bien dancer (Geneva, 1985). For a collated modern edn. see Fifteenth Century Basse Dances. The Wellesly Edition 6, ed. James L. Jackman (Wellesley, 1964, Reprint New York 1980). For further information see Frederick Crane, Materials for the Study of the Fifteenth Century Basse Danse (New York, 1968), and Raymond Meylan, L'énigme de la musique des basses danses du quinzième siècle (Berne, 1968).

94 Notably by Keith Polk; see the information conveniently gathered together in his German Instrumental Music (cf. fn. 61). 
notated polyphonic songs. Several fifteenth-century sources transmit collections of tenors drawn straight from such compositions. In one instance F-Pn, n. a. fr. 4379-III (fols. 61-8) - we may be dealing simply with a partbook whose companion parts are no longer extant. ${ }^{95}$ At least its tenors all seem to be notated in much the same way as might be expected had they been set out more conventionally on the same opening as their companion voices. In particular, refrain texts are pre-inscribed below the staves whenever the musical articulation of the tenor seems designed for them, but are otherwise absent. In other sources, however, tenors that derive, or seem likely to derive from written polyphony are notated in a manner suggestive of use in group improvisation. Cases in point include the several musical items Noël de Fleurus and later his son Jean de Fleurus dit Taillefer (and others) jotted down at various times between the 1420s and 1470s on the back of deeds and other official records for the town of Namur in the Brabant. ${ }^{96}$ Here the music is in a simple stroke notation, representing rhythmically simplified versions of mensural melodies, such as might be useful to musicians accustomed to notationless performance for whom a training in complexities of polyphonic mensural music notation would have served little purpose. $^{97}$

Again, there is little if anything about the Namur tenors to suggest a rigid distinction between vocal and instrumental use. Instrumentalists could have adopted any of them as basis for polyphonic improvisation. But many are accompanied by the texts for which the untransmitted discantus voices had been fashioned, and in some instances texts appear without any notated music at all. In the circumstances there is the possibility, even likelihood, that they served for extempore vernacular singing too. This is hardly surprising. After all, such theoretical information as we have concerning improvising super librum, to say nothing of anecdotal evidence, largely relates to vocal practices. ${ }^{98}$

With some stroke notations, however, instrumental performance seems the only realistic possibility. One series of examples comprises the lower

95 David Fallows, »The Early History of the Tenorlied and its Ensembles, « Le concert des voix (cf. fn. 29), p. 203. I am grateful to David Fallows for letting me see his photocopies of the manuscript.

96 B-NA. They are edited, with facsimiles, in Ernest Montellier, »Quatorze Chansons du $\mathrm{XV}^{\mathrm{e}}$ siècle extraites des Archives Namuroises, «Commission de la Vieille Chanson populaire, Annuaire 1939 (Antwerp, 1939), pp. 153-213.

97 On sources with stroke notation see Jan van Biezen and Kees Vellekoop, »Aspects of Stroke Notation in the Gruuthuse Manuscript and Other Sources, « Tijdschrift van de Vereniging voor Nederlandse Muziekgeschiedenis 34 (1984), pp. 3-25.

98 See, for example, the extensive citations in Wegman, From Maker (cf. fn. 92). 
voices of John Dunstaple's »Puisque m'amour«, various duets on them, and four other tenors, all jotted down in the 1440s in a book belonging to Venetian trombonist Zorzi Trombetta, apparently for use by a ship's musician. ${ }^{99}$ Then there is Quene note, one of three tenors noted in the third quarter of the fifteenth century on a page from a book of calendars and astronomical tables, to which some one has added a discant in ordinary mensural notation that, as often remarked, any instrumentalist could have improvised. ${ }^{100}$

An initially unnotated tradition of making counterpoints on tenors drawn from pre-existent polyphonic songs is surely a major impetus for the creation of a body of fully notated such settings that can be identified in musical sources from the 1440s, and to which Agricola contributed more extensively than any other composer of his time. Tinctoris described the compositional technique in the Liber de arte contrapuncti (dated 1477 in one contemporary copy): ${ }^{101}$

Super cantum autem figuratum contrapunctus fit quotiens tenore ex notis certi valoris iuxta perfectas aut imperfectas quantitates mensuratis composito super cum concinitur.

Counterpoint, however, is made on figured song, whenever, with a tenor made up of notes of a certain value, measured in terms of perfect or imperfect quantities, harmony is made over this.

His accompanying music examples, with their tenors drawn from Latin polyphony ${ }^{102}$ and mensural chant, represent texted vocal traditions. Agricola's settings of comparable vernacular cantus figuratus tenors include one - »Allez regretz« - that may be similarly conceived for words (those of

99 GB-Lbl, Cotton Titus A.xxvi. See Daniel Leech-Wilkinson, »Il libro di appunti di un suonatore di tromba del quindicesimo secolo, « Rivista italiana di musicologia 16 (1981), pp. 16-39.

100 GB-Ob, Digby 167, fol. 31 ; facs. in Early Bodleian Music: Sacred o Secular Songs Together with other Ms Compositions in the Bodleian Library, Oxford, ed. Sir John Stainer (London, 1901), vol. 1, pl. 98. The other two stroke-notation tenors are those of the three-voice song »Aux ce bon joure de la bonestren« (complete, though without words, in Trent 87, I-TRbc, 1374, fols. $117^{\mathrm{v}}-118^{\mathrm{r}}$ ) and of the hymn faburden »Eterne rex altissime

101 See Johannis Tinctoris Opera theoretica. Corpus Scriptorum de Musica 22, ed. Albert Seay (American Institute of Musicology, 1975), vol. 2, chapter 22, pp. 117-21, quotation from p. 117; translation by A. Seay in Johannes Tinctoris, The art of Counterpoint. Liber de arte contrapuncti. Musicological studies and documents 5 (American Institute of Musicology, 1961), pp. 110-12, quotation from p. 110.

102 The example in question bears text from the Sanctus in the Liber de arte contrapuncti, but in another copy of it in $\mathrm{I}-\mathrm{Bc}, \mathrm{A} 7 \mathrm{l}$ it has the incipit $\gg \mathrm{Si}$ vis«, while in two further copies in I-PEc, 1013 it has no text at all. 
Hayne's original chanson? or just possibly those indicated in one source I-Rvat, C. G. XIII.27 - by the Spanish incipit »No me canteys a la primera $\ll)$. However, the others, being surely wordless in conception, and saturated with the kinds of device we can associate readily with group improvisation, seem self-evidently destined from the start for instrumental performance (the occasional incidence of contrafactum texts notwithstanding) ${ }^{103}$

Agricola probably made such wordless cantus figuratus settings throughout his working life. In all save two cases he accepts the original tenor as his own tenor unchanged, just as, one assumes, improvising bands did. This contrasts with his procedure when using material drawn from pre-existent polyphony in the mass settings (Missa Je ne demande, Missa Le serviteur, Missa Malheur me bat), where the cantus firmus treatment tends to be much more flexible. The former relates to a polyphonic tradition that is improvised in performance; the latter one of composed polyphony for performance. His two-voice setting of the tenor of Binchois's rondeau »Comme femme (found only in the Segovia Manuscript) sounds close to putative spontaneous improvisation, and might be relatively early on that account (notwithstanding the didactic function that characterizes much two-voice composition, making it difficult to be confident about dating). His two further Comme femme settings - one a 3 and one $a 4$ - must have been completed by the end of the 1480 s, to judge from their earliest sources. ${ }^{104}$ So too must at least one of the five settings of the tenor of Hayne's rondeau $» D e$ tous biens plaine «. ${ }^{105}$ Perhaps also by the same date, although their earliest transmission is from around the turn of the century, are Amours amours, De

103 In my Songs Without Words (cf. fn. 84) I used the expression »res facta « to characterize the tenors for such settings. Strictly speaking, this is correct, but because its meanings are rather specific (see Margaret Bent, »>Resfacta< and >Cantare Super Librum<, «ournal of the American Musicological Society 36, 1983, pp. 371-91, and Bonnie J. Blackburn, »On Compositional Process in the Fifteenth Century«, Journal of the American Musicological Society 40, 1987, pp. 210-84), and not so easily explained, I now prefer Tinctoris's much more readily grasped »cantus figuratus $«$. Admittedly the expression Honey Meconi coins for the title of her useful essay on this genre - »Art-Song Reworkings: An Overview, « Journal of the Royal Musical Association 119 (1994), pp. 1-42 - also has its merits (rehearsed at the beginning of the article), though the built-in anachronism can be hard to take.

104 With Latin Marian contrafact texts both Comme femme settings appear in Gathering XII of D-B, Mus. 40021 (1493-4/5); the three-voice setting, apart from turning up eventually among the Trium vocum carmina Agricola compositions, is also in I-Rc, 2856, on whose uncertain date see above.

105 Alexandri Agricola Opera omnia, vol. 5 (cf. fn. 51), no. 52, pp. 78-9; it is in I-Rvat, C. G. 27 (dated 1492-4). 
tous biens plaine (the two settings in the Segovia Manuscript), ${ }^{106}$ D'ung aultre amer a 3 (the Segovia setting), ${ }^{107}$ Tout a par moy a $4,{ }^{108}$ and T'Andernaken. ${ }^{109}$

The last mentioned, however, differs from the others by presenting, in much embellished form, an older tenor whose title indicates an association of some kind with a set of narrative Flemish verses far removed in their quasi-popular caste from the world of French courtly rondeaus. This tenor does not itself behave like a word-bearing popular melody though. It has, in fact, all the characteristics one might expect of a wordless tenor in a polyphonic song with word-bearing discantus. ${ }^{110}$ Indeed, the original song in question might well have been that uniquely transmitted in the 1440s manuscript Trent 87 (I-TRbc, 1374) with ascription to one Tyling (or perhaps $»$ tijling « or »tyting «), for although it is untexted in this source its discantus readily accepts the $» T^{\prime}$ Andernaken« popular verses, as Jan Willem Bonda showed. ${ }^{111}$

Six settings are transmitted only in posthumous sources (I-Fc, Basevi 2439 included): De tous biens plaine (two further settings a 3), ${ }^{112} D^{\prime} u n g$ aultre amer (one setting $a 3$ - with tenor from Ockeghem's discantus, rather than his tenor, and treated with even more liberties than was the case with the T'Andernaken tenor - and two settings a 4$),{ }^{113}$ and Tout a par moy a 3.

106 Ibid., nos. 55-6, pp. 82-4.

107 Ibid., no. 60 , pp. 88-9.

108 Ibid., no. 63 , pp. $92-5$.

109 Ibid., no. 67, pp. 99-101.

110 Compare the tenor La belle se siet, inscribed in stroke notation in the Namur documents cited above, along with popular French narrative verses it can scarcely have been designed to bear. It surely originated as an integral part of the anonymous two-voice setting found in I-Bu, 2216 whose discantus is plainly crafted for the same words that appear with it there. For full details of early transmission - including Guillaume Dufay's adaptation with added triplum - and subsequent citations see David Fallows, A Catalogue of Polyphonic Songs 1415-1480 (Oxford, 1999), pp. 228-9.

111 Jan Willem Bonda, »T'Andernaken between Bruges and Ferrara, « From Ciconia (cf. fn. 56), pp. 49-74. Bonda saw the T'Andernaken tenor as »meant for the improvisation of a Discant above it« (p. 50), a view that cannot be ruled out. However, I find it much harder to accept his line of reasoning that for subsequent native Dutch speakers like Agricola, familiar with the $\gg$ T'Andernaken« verses, the act of composing a polyphonic setting of their associated tenor for anything other than voices would have been inconceivable, or to follow the argument that led him to conclude that for Agricola's setting, "vocal performance may be difficult but it seems the only way in which this complex composition could make sense ... In listening to it one needs the information of the text to structure the music ... The only way to appreciate an instrumental version ... is by realizing that it was originally intended for vocal performance« (pp. 66-7).

112 Alexandri Agricola Opera omnia, vol. 5 (cf. fn. 51), nos. 53-4, pp. 79-82.

113 Ibid., nos. 57-9, pp. 85-8. 
And while late transmission does not in itself rule out an early date of composition, there is perhaps something about their expansiveness and confidence to suggest that they are indeed from his last years.

If we can be reasonably confident of an initially instrumental destination for most of Agricola's cantus figuratus settings we may as well speculate about some of the particular instrumentalists he might have had in mind for them at different stages in his career. To judge from documentary and iconographical evidence, in conjunction with the musical sources referred to above, there was no shortage on the Franco-Burgundian axis of instrumentalists whose skills at improvising on a tenor might be harnessed to this end. Among them in the 1480s were surely Charles and Jehan Fernandes, already alluded to in connection with Cecus, given their documented service with Charles VIII in at least 1488 and 1490 , by which time Agricola was almost certainly a colleague. ${ }^{114}$ The presence of six settings in the Agricola canon that could have been composed during his final years in Philip the Fair's grande chapelle, opens up the intriguing possibility that Agricola composed them with Augustin Schubinger, and other instrumentalists in Philip's entourage at that time, specifically in mind. We noted above Schubinger's occasional participation as cornettist with the chapelle. ${ }^{115}$ That he also played the lute at this time is documented in a 1504 court record of payment for his services in Spain. ${ }^{116}$

Of course the question arises as to whether Agricola himself took part in instrumental performances of his own compositions. That would seem highly likely, his assumed primary activity as singer notwithstanding, although the only evidence that he played as well as sang is the rather tenuous statement in the much later musical Epitaphion Alexandri Agricolae Symphonistae regis Castiliae Philippi that he was »clarus vocum manuumque $\ll .{ }^{117}$

114 On the Fernandes' royal service see Pirro, L'Enseignement (cf. fn. 75), p. 46, citing F-Pn, fr. 32779 , fols. $384^{\mathrm{r}}$ and $392^{\mathrm{v}}$, copied in the eighteenth century from early records now untraced.

115 Schubinger is documented at the Burgundian court from November 1500 to at least October 1503; see Polk, The Schubingers (cf. fn. 52).

116 Vander Straeten, La musique (cf. fn. 52), p. 149.

117 Uniquely transmitted in Rhau's above-mentioned Symphoniae iucundae (1538), and discussed most recently in Tess Knighton, » >Music, why do you weep? A Lament for Alexander Agricola (d. 1506), «Early Music 34 (2006), pp. 427-41. Kämper’s statement (in Instrumentale Stilelemente, cf. fn. 86, p. 2), occasionally repeated, that Agricola was a lutenist has no secure foundation. It comes about from taking the words »Alexandre Agricola, chantre de nostre chappelle, et ung bon joueur de luz«, in Charles VIII's letter to Piero de' Medici requesting the composer's return to France, out of context (see Martin Picker, »A Letter of Charles VIII of France Concerning Alexander Agricola, « 


\section{The Italian fallacy}

The view of Agricola's wordless cantus figuratus settings, and possibly his other instrument-orientated compositions, as product of lifelong activity compels a reconsideration of the received view (quoted above) that compositions for instrumental ensemble in Italian sources represent »the chief focus of secular composition by Franco-Netherlanders in Italy«. This is something I too once took for granted. ${ }^{118}$ However, with Josquin's first documented presence in Italy now set back from 1459 to 1484, a year before Isaac's arrival, perhaps when both composers were at least thirty - and with Agricola's Florentine residence of the 1470s now disproved and his known visits confined to 1491-2, and a sojourn of unknown length beginning in 1494, the case for identifying a school of instrumental composition attributable to »northerners active at Italian courts« begins to look pretty thin.

Even those foreign composers known to have been in Italy much earlier do not necessarily bolster it. Johannes Martini's most famed >song without words<, La Martinella, was copied without title into Trent 89 (I-TRbc, 1376) long before he took up permanent residence at the Ferrarese court in 1473. Admittedly it is distinctly possible that the piece was entered into the virtually completed manuscript in 1466, in which year Martini may well have visited the court in the company of one of its former employees, Nicolaus Krombsdorfer, now organist and principal singer to Duke Sigismund of Austria. However, Martini's main activity at this time was surely somewhere north of the Alps. ${ }^{119}$

This raises the very real possibility that the major part of his other compositions transmitted without words in Italian sources - many of them rondeau-like, and/or with French titles - may indeed have begun life as conventional chansons, complete with words. ${ }^{120}$ What characterizes the

Aspects of Medieval and Renaissance Music: A Birthday Offering to Gustave Reese, ed. Jan LaRue, New York, 1966, p. 665-72, and Plate 23a). The lute player is not Agricola, but is in his company (»en sa compaignie«). Moreover Charles requires that Agricola not only comes before him but that he brings with him the said lutenist (»qu'il s'en vienne devers nous et qu'il amene avec luy ledit joueur de luz«).

118 Songs Without Words (cf. fn. 84), p. 91. See also Meconi, Art-Song Reworkings (cf. fn. 103), pp. 21-2.

119 See Reinhard Strohm, »Die vierstimmige Bearbeitung (um 1465) eines unbekannten Liedes von Oswald von Wolkenstein, « in: Jabrbuch der Oswald von Wolkenstein Gesellschaft 4 (1986/87), p. 171; ibid., The Rise (cf. fn. 79), p. 521.

120 Reinhard Strohm, citing my Songs Without Words (cf. fn. 84), p. 80, graciously endorsed the listing there of the principal Franco-Netherlanders to produce the subjects of my study (The Rise, cf. fn. 79, pp. 535-6), but called me to account for omitting the name of Martini. I am unrepentant! 
contents of late fifteenth-century Italian chansonniers is their concentration - often obsessively - on compositions by foreigners, irrespective of where they lived. Most of Martini's secular music, in fact, circulated little beyond the Ferrarese manuscript Rome 2856 and the Florentine Braccesi chansonnier I-Fn, B. R. 229. (Did his long residence at Ferrara, and the Italianate form of name he adopted, even serve to inhibit the collectability of his music?) Busnoys, on the other hand, never went to Italy, as far as we know, yet his music seems to turn up everywhere.

Indeed, that is not the only irony to flow from the current widely held view of Italy as crucible for the composition and performance of instrumental ensemble music in Agricola's time, and hence the implied marginalization of France in this regard. After all, the only extant musical source from Agricola's time to have emerged from this study as unequivocally designated for instrumental performance has turned out to be the Michel de Toulouze dance manual - printed in Paris.

\section{III »Musik zwischen Vokalität und Instrumentalismus«}

In conclusion - and in deference to the title of this volume - I have to say that to Agricola and his contemporaries the idea that music (whether >composed or improvised) might be conceptualized as either vocal or instrumental would have been surprising. Still more so would have been the notion that it might occupy a »Grauzone zwischen Vokalität und Instrumentalismus $\ll .{ }^{121}$ Perhaps the perceived problem that the expression »grey area « here connotes lies simply in the fact that the parameters in question are of purely modern invention. For Agricola voices and instruments shared repertories and approaches to performance to the extent that the voice simply was an instrument. What separated the two categories in practice (apart from their material attributes) was first and foremost function: the repertory used for worship in cathedrals and chapels, for example, might be said to be vocal (at least in normal circumstances); that for the accompaniment of courtly dance instrumental. But to judge from its circulation, Agricola must have conceived most of his music on the assumption that, once it had served its immediate purpose (of which we have very little knowledge), it would be reused, adapted as required, for a variety of functions that might characteristically be associated with either voices or instruments, or with both, or indeed with neither (in the case of certain kinds of pedagogical books or 
presentation manuscripts, for example). In the circumstances discussion of his music or of its notated circulation in terms of such classification is bound to run into insuperable difficulties.

Admittedly Agricola's generation would probably be just as bemused by the idea of >songs without words<, at least as a means of classification at the point of composition. ${ }^{122}$ At this period the conscious preoccupation in all genres was, as I contend above, with music, rather than with the expression of words in the sense that later generations (including ours) would come to understand. Hence the fallacy behind the assumption that composers themselves saw the words they set, or those associated with the pre-existent melodies they elaborated, as necessarily defining their works. And hence the ultimate impossibility of achieving a systematic separation of compositions intended for words from those not. ${ }^{123}$

Nevertheless it is legitimate - not to say vital - to seek an understanding of those aspects of the chiefly unnotated music instrumentalists traditionally performed that might have struck Agricola and his contemporaries as sufficiently distinct from anything to come from the throat of a singer to impact on their compositional style in a way that might itself be characterized as sinstrumentalk. The key, I suspect, lies in creative process, rather than in the specific attributes of this or that musical instrument. Captivated, like no other composer of the time, with the techniques and processes of improvisation, Agricola sought to explore how aspects of this fleeting art might be incorporated into and perpetuated in figured music. As noted above, such performance skills were not limited to instrumentalists, but to judge from contemporary reports of star players like Pietrobono, the Fernandes brothers, Augustin Schubinger, and the like, they were what instrumentalists of the time - Agricola perhaps included - deliberately cultivated, and through which the best of them persistently out-performed singers. By turning their traditions to compositional use Agricola could reiterate the words of Tinctoris, quoted above, concerning the sounds that »ad contemplationem gaudiorum supernorum ardentissime cor meum inflammant«.

122 The Benedictus from Isaac's Missa Quant j'ay an cuer, which circulated widely without its words, is labelled »Absque verbis« (»without words«) in F-Pn, Rés. Vm 676 and I-Bc, Q 18.

123 Jon Banks's The Instrumental Consort Repertory of the Late Fifteenth Century (Aldershot, 2006), with its central chapter on »Defining the Repertory«, reached my desk only after this article was finished and about to go to press. 


\section{Appendix}

Preface to Trium vocum carmina a diversis musicis composita (printed by Hieronymus Formschneider, Nuremberg, 1538) from the tenor part book (after microfilm of Jena copy, collated with Howard M Brown, Instrumental Music Printed before 1600: A Bibliography (rev. reprint, Cambridge, Mass., 1967), p. 59. English translation by Leofranc Holford-Strevens.

\section{CANDIDIS MUSICIS SALUTEM}

En damus vobis magno numero delecta trium vocum Carmina, á probatissimis Musices professoribus, tum veteribus tum recentioribus composita.

Congessimus autem ea singulari studio, non eò solum, ne suavissima summorum in hoc genere ingeniorum monumenta perirent, sed ut etiam iuventutis studia accenderemus ad artem longè omnium suavissimam diligenter complectendam.

Notae enim sunt non solum veterum Graecorum Poetarum, Theognidis, Homeri, \& aliorum insignes commendationes, quibus Musicam ornarunt, tanquam perpetuam honestatis et eruditionis comitem, sed etiam Philosophorum iudicia non obscura extant, quae testantur ad Rempublicam pertinere, ut iuventus diligenter discat Musica.

Quod si nihil haberet haec ars praeter illam suavitatem ac oblectationem, an non satis magna ea commendatio esset: praesertim cum haec vita ob curas \& negotiorum varietatem non possit esse iucunda, nisi aliqua docta suavitate condiatur.

Existimamus igitur hoc studium nostrum omnibus bonis probatum iri, quod \& Reipublicae ac iuventutis commodis consulimus, \& suavissimos labores insignium Musicorum ab interitu vindicamus.

Quia autem Carmina haec non unius linguae verba habebant, commodius fore iudicavimus, si obmissis verbis, carmina signaremus numeris.

\section{TO FAIR-MINDED MUSICIANS, GREETING}

Look, we give you in great number choice songs for three voices, composed by the most approved exponents of music, both ancient and modern.

We have collected them with singular enthusiasm, not only so that the sweetest productions of the greatest minds in this field should not be lost, but also that we might kindle the enthusiasms of youth to painstakingly embracing this art, by far the sweetest of all.

For well known are not only the notable commendations of the ancient Greek poets, Theognis, Homer, and others, with which they honoured music as the constant companion of uprightness and learning, but there are also far from obscure judgements of the philosophers that attest it to be in the interest of the state that youth should diligently learn music.

But even if there were nothing to this art besides that sweetness and delight, might that not be a sufficient commendation of it, especially since this life, owing to our worries and our many different kinds of business, cannot be pleasant unless it be flavoured with some cultured sweetness? We therefore think that this enthusiasm of ours will be approved by all good men, since we are both taking thought for the advantage of the state and of youth, and rescuing the sweetest labours of notable musicians from perishing.

But since the words of these songs were in several languages, we judged that it would be more convenient if we left out the words and designated the songs by numbers. 
Deformitatem enim res habitura videbatur si nunc Germanica, nunc Gallica, nonnunquam Italica, aut latina commixta essent.

Deinde in trium vocum carminibus videntur artifices magis sonorum eruditam mixturam spectasse, quám verba.

Hac voluptate eruditus Musicus abunde fruetur, etiam si nulla subiecta verba sint.

Neque de Autorum nominibus valde fuimus soliciti, quod singuli suas insignes notas habeant, quibus ab eruditis Musicis facile possint agnosci.

Bene valete, et fruimini feliciter laboribus nostris. Nam huius generis alia quoque dabimus. Deo aspirante.
For it appeared that ugliness would result if now German texts, now French, sometimes Italian or Latin, were mingled together.

Then, in songs for three voices, the craftsmen seemed to have been more concerned with a well-trained mingling of sounds than with words.

The trained musician will enjoy this pleasure in abundance, even if no words are underlaid.

Nor did we take much care over the composers' names, since they each have their own notable characteristics, by which trained musicians may easily recognize them.

Farewell, and enjoy our labours in happiness, for we shall give (you) other things of this nature too, if God breathe his favour upon us. 